\title{
Az elemi népoktatás viszontagságai a XIX. század második felében a korabeli törvények tükrében egy nagyközség, Romhány példáján keresztül
}

\author{
MÉszÁros ÁdÁM \\ Magyar Nemzeti Levéltár Heves Megyei Levéltára \\ Eszterházy Károly Egyetem Történelemtudományi Doktori Iskolája
}

\begin{abstract}
A magyar oktatásügy a 19. század második felében gyökeres átalakuláson ment keresztül, ugyanis az 1868-as népoktatási törvény új alapokra helyezte azt. A törvény által elöírt rendelkezések azonban csak nagyon lassan kezdték éreztetni hatásukat, hiszen az ország sok tanodája nem tudott megfelelni az előírásoknak. Tanulmányunkban a legalapvetőbb problémákat egy nagyközség, Romhány népiskolájának példáján keresztül mutatjuk be, túlnyomórészt elsődleges források alapján.

Kulcsszavak: népoktatási törvény, tankötelesek és iskolába járók aránya, ismétlő iskola, faiskola, taneszközök, segédtanítók
\end{abstract}

A XIX. század második fele Magyarországon egy olyan időszak volt, amelyben a népoktatás ügye folyamatosan fontos kérdésnek számított, s az oktatásügy egyértelmú fejlődésnek indult, de ezt számos probléma nehezítette. Tanulmányunkban Romhány község példáján keresztül megvizsgáljuk, hogy milyen viszontagságokon kellett keresztülmennie egy nagyközségi elemi népiskolának. Természetesen a községi adatokat - ahol csak lehetséges - össze kell vetnünk az országos, illetve vármegyei trendekkel is. Romhány község népiskolája annak ellenére is sok problémával küzdött a vizsgált időszakban, hogy az iskolába járók aránya szinte végig meghaladta az országos, sőt az országosnál jobb vármegyei mértéket is. Problémái között fenntartási, infrastrukturális és személyi problémák sokaságát találjuk. A következőkben ezek részletes vizsgálatát végezzük el.

ROMHÁNY OKTATÁSI VISZONYAI A XVIII. SZÁZAD vÉGÉN ÉS A XIX. SZÁZAD ELSŐ FELÉBEN

A magyar oktatás elhanyagoltságát felismerve, annak fejlesztéséért Mária Terézia tett sokat, s a felvilágosult abszolutizmus alapelveinek érvényesítésével 
igyekezett egységes - osztrák - irányítás alá vonni. A királynő a közoktatás megreformálását az 1777-ben kiadott I. Ratio Educationis értelmében hajtotta végre. Csaknem 30 évvel később, 1806-ban I. Ferenc király kiadta a II. Ratio Educationist, amely a Mária Terézia-féle Ratio hiányosságait volt hivatott orvosolni. A dokumentum előírta az alapfokú oktatás ingyenességét, valamint a 6-12 éves korú gyermekek kötelező iskoláztatását. Ha a szülőnek felróható hibából a gyermek nem járt iskolába, akkor a szülő pénzbüntetést kapott. Rendelkezett arról is, hogy a tanító, illetve segédtanító kinevezésének feltétele legyen a tanítóképző elvégzése. A két Ratio tehát alapvetően igyekezett szabályozni az iskoláztatást s a XIX. század közepéig ezek határozták meg a tanügyet (Nóbik és Pukánszky, 2015). 1845-ben azonban az iskolázás története újabb mérföldkőhöz érkezett, ugyanis ekkor kibocsátottak egy helytartótanácsi rendeletet az elemi tanodák szabályairól. A rendelet két részre osztotta az elemi iskolát; az 1. és 2. osztályból álló alsó elemire, illetve a 3. és 4. osztályból álló felső elemire. Az alsó elemi iskolákban a mindennapi élethez szükséges alapvető ismereteket adták át a gyermekeknek, a felső elemi iskolákban pedig a továbbtanulni kívánó gyermekek képzése, felkészítése folyt. A Helytartótanács külön tanodák építését rendelte el a férfi és a női nem számára, s ahol ez nem volt lehetséges, ott külön időpontban kellett az eltérő nemú gyermekeket oktatni, vagy külön padokba ültetni. Az alsó elemi iskoláknak ekkor rendszerint csak egy tanítója volt, de igény szerint tarthatott segédtanítót. A hitoktatást a település lelkésze, vagy káplánja végezte. A rendelet értelmében a tanítás egyetlen teremben történt, azonban ha a tanulók száma meghaladta a 100 főt, gondoskodni kellett egy másik tanterem felállításáról. ${ }^{1}$

Az 1848/49-es forradalom és szabadságharc hívei gyökeresen át akarták alakítani a magyar közoktatásügyet, amelynek rendszerét Eötvös József dolgozta ki törvényjavaslat formájában, melyet július 24-én terjesztett az országgyúlés elé. Ennek legfontosabb elemei a következők voltak: az államnak gondoskodnia kell arról, hogy minden helységben legyenek népiskolák, a tanításnak ingyenesnek kell lennie, a tanodák fenntartása a község lakosságára kivetett iskolaadóból valósult meg, az oktatásnak anyanyelven kellett történnie, kötelező tantárgyként írták elő az írást, olvasást, számtant, természettant, természetrajzot, magyar történelmet, földrajzot, polgári-jogi ismereteket, testnevelést és az éneket. A vallástant nem tekintették iskolai tantárgynak, csak abban az esetben, ha az adott községben egyazon felekezetből 50-nél több tanköteles gyermek él. A törvényjavaslat a tankötelezettséget fiúknál 6-12 éves korig, lányoknál 6-10 éves korig határozta meg. Eötvös törvényjavaslatának megvitatását az országgyúlés „békésebb időkre” halasztotta. A szabadságharc leverése és az önkényuralom miatt azonban erre csaknem 20 évet kellett várni (Mészáros, Németh és Pukánszky, 2003. 301-302. o.).

A XVIII. század végének és a XIX. század első felének tanügyi viszonyait

1 MNL OL, C, Helytartótanácsi Levéltár, Magyar Királyi Helytartótanács regisztratúrája, C 69 Departamentum scholarum nationalium, Normalia, 1845. F. 19. 74. o. 
áttekintve vizsgáljuk meg, hogy választott községünkben miként alakult az iskolázás ügye, s mennyiben tért el az országos viszonyoktól. A romhányi iskola alapításának körülményei sajnos a múlt homályába vesznek. Az első írásos emlékeink az iskolával kapcsolatosan az 1770-es évekből valók, bár a keresztelési anyakönyvet lapozva 1703-ból találhatunk egy bejegyzést, mely a következőképpen szól: „[...]ludimagistro Romhan: András Deák". ${ }^{2}$ Tehát a községben 1703-ban már volt tanító, így feltételezhetjük, hogy iskola is. Mivel a török idők alatt a település csaknem teljesen elpusztult, s plébániáját is 1702 végén állították fel újra, feltételezhetjük, hogy az iskolát is ekkor létesítették. Az első biztos információnk a tanoda létezéséről 1770-ből származik. Ekkor a tanítóösszeírás megemlíti, hogy a faluban a tanítási feladatokat Lissay János látta el, a gyermekeknek írást és olvasást tanított. ${ }^{3}$ Az 1772, 1773 és az 1774-es évekből szintén maradtak fenn tanítóösszeírások, melyek már pontosabb információkat szolgáltatnak. A tanító még ekkor is Lissay János volt, azonban megtudjuk, hogy Püspökhatvanból származott, és 1769-től látta el a tanítási feladatokat a községben.

A tanulók létszáma ebben az időben 50 és 60 között mozgott. A tantárgyakra nézve némi pontatlanságot fedezhetünk fel. A váci püspöknek küldött jelentések szerint a tanulók írást, olvasást, szótagolást, illetve vallástant tanultak. A számtant következetesen nem említik meg, amelynek okát sajnos nem tudjuk, ugyanis a Mária Terézia által elrendelt összeírások a számtan tanításáról is említést tesznek. Az összeírások és jelentések beszámolnak a tanító fizetéséről is, melynek alapján a tanítói javadalom a párbérból, a stólajövedelemből, illetve természetbeni jövedelemből tevődött össze. Mivel az 1772-es iskolai jelentés temetési stólajövedelmet is említ, így a tanító minden bizonnyal kántori feladatokat is ellátott. ${ }^{4}$ Ezt követően 1789-ig nincs adatunk az iskoláról, amikor egy tanítói jövedelem-összeírásban részletesen taglalják a tanítónak járó jövedelmeket. A tanító ekkor már Strihó István, összes évi jövedelme pedig 125 rajnai forint 12 2/5 krajcár volt. A javadalmazás a következőkből tevődött össze; az iskolamester rendelkezett telekjövedelemmel, melybe beletartozott a szántóföldből, a házikertből, a kenderföldből, illetve a káposztásföldből származó haszon. A szántóföldből származó jövedelmeket búza-rozs keverékében, rozsban, illetve zabban kapta, mértékük 11-20 pozsonyi mérő között ingadozott, évtől függően. A telekjövedelem mellett - mivel kántortanító volt - rendelkezett egyházi jövedelemmel, vagyis stólajövedelemmel is, melyet a hívek fizettek temetések és házasságkötések után. Ennek értéke temetésenként 15 krajcár, házasságkötésenként pedig 7 krajcár volt. Ezeken kívül a lakosságtól megillette őt deputátumként pénzben páronként 15 krajcár párbér, természetben pedig

\footnotetext{
2 VPKL Plébániai levéltár, A romhányi r.k. plébánia iratai, Anyakönyvek, Liber baptizatorum, matrimoniorum et defunctorum, 1702-1733.

3 MNL NML IV-1/b 390. doboz, 2. Tanítók 1770-1773, Tanítók összeírása, 1770.

4 MNL NML IV-1/b 390. doboz, 2. Tanítók 1770-1773, Tanítók összeírása, 1772-1773.

VPKL Püspöki levéltár, Váci Püspöki Hivatal iratai, Iskolai iratok, Informatio scholaris, 1. doboz 1770-1852, A romhányi plébánia tanítóinak összeírása, 1770-1774.
} 
páronként $1 \frac{1}{2}$ pozsonyi mérő búza, a lakosságtól pedig egy fél szalonna, 50 font só, 4 icce vaj, 4 font faggyú, 2 kocsi széna, valamint 12 öl túzifa. A tanulók tandíj címén évi 10 forintot fizettek. ${ }^{5}$

Az 1789-es összeírást követően évtizedekig nincs információnk az iskoláról. 1818-ban azonban ismét említik a források a település tanodáját egy nagyobb mértékú felújítás kapcsán. Ekkor megtudjuk, hogy a száznál több iskolás gyermek miatt szükség volt az iskolai tanterem kibővítésére, de egyúttal a tanítói lakást is fel kellett újítani. ${ }^{6}$ Az iskola - a kántorlakkal együtt - röviddel a felújítás után, 1824 nyarán leégett, melyeknek újjáépítésére a püspök 282 váltóforintot adományozott (Chobot, 1913. 35. o.). 20 évvel később, 1844-ben ismét szükségessé vált az iskola renoválása, illetve átépítése.

Az építkezéshez Géczi Elek és Prónay János földbirtokosok 100 illetve 25 forintot, a plébános 100 forintot adományozott, mely összeghez még a község hozzáadott 200 forintot, továbbá a nyersanyagot és a munkaerőt. Így tehát az építkezésre 425 forint állt rendelkezésre. Az átépítést 1844 májusában kezdték meg, s az elkészült iskolaépületben volt egy $5^{4} / 6$ öl hosszúságú és 3 1⁄2 öl szélességú tanterem, valamint a kántortanítónak és a harangozónak lakás. A plébános ezen felül még 150 forintot a községnek adományozott, hogy az utómunkálatokat befejezzék. Ennek köszönhetően 1845-re fejeződött be az új iskola építése (Chobot, 1913. 42. o.).

\section{A ROMHÁNYI ISKOLÁZÁS HELYZETE AZ ÖNKÉNYURALOM IDŐSZAKÁBAN}

Az 1848/49-es forradalom és szabadságharc leverése után az országra nehéz idők köszöntöttek. A Habsburgok újra bevezették az abszolutisztikus kormányzást, mellyel céljuk Magyarország Habsburg Birodalomba való beolvasztása volt. Ezzel párhuzamosan igyekeztek serkenteni a polgári átalakulást, természetesen az 1848-as alapoktól eltérve, osztrák mintára. Ez az intézkedés jelentős hatást gyakorolt az 1850-es évek oktatásügyére. Az osztrák kormányzat törekedett arra, hogy minél több gyermeket részesítsenek legalább népiskolai oktatásban. A fő felügyeletet ezen a téren is az állam gyakorolta, tehát a centralizáció ezen a téren is megvalósult. Az alapfokú iskolákban is kötelezővé tették a német nyelv tanítását, s magyarra fordított osztrák tankönyvekből tanítottak. Az 1850-es évek első felében a már említett 1845. évi helytartótanácsi rendelet maradt érvényben, tehát az elemi iskola továbbra is két részből állt; az alsó 2 osztályból, a felső szintén 2 osztályból. 1855-ben azonban némi változás következett be,

5 VPKL Püspöki levéltár, Váci Püspöki Hivatal iratai, Iskolai iratok, Acta scholastica, 1. doboz 1736-1845, Összeírás Nagy-Romhány falu tanítójának összes jövedelméről és előírt illetményéről, 1789.

6 VPKL Püspöki levéltár, Váci Püspöki Hivatal iratai, Acta Parochiarum, Romhány, 1. doboz 1774-1869, 392/818. A romhányi plébániaépület tetejének javítása és a felsőbodonyi helyi iskolaház felépítése, 1818. 
ugyanis a kormányzat által kiadott rendelet értelmében már két típusú elemi iskola létezett; a fóelemi és az alelemi. A főelemi iskolák 4 osztályból álltak, főként városokban voltak jellemzőek. Az alelemi iskolák ezzel szemben csak 2, illetve 3 osztályból álltak, s tulajdonképpen ez az iskolatípus felelt meg a falusi népiskoláknak. Ezekben az iskolákban a tanító gyakran száznál is több gyermekkel foglalkozott egyidejúleg, egyetlen tanteremben. 1858-tól azonban az alelemi népiskolai oktatást is 4 osztályosra bővítették ki. A népiskolák szellemi vezetését az egyház látta el, ugyanis 1849-ben előírták, hogy különösen nagy hangsúlyt kell fektetni a gyermekek vallási és erkölcsi nevelésére. 1868-ig tehát csak egyházi fenntartású népiskolák léteztek Magyarországon, a községek többnyire csak a tanodák anyagi fenntartásához járultak hozzá. Az 1850-es években az elemi iskolák száma jelentős mértékben növekedett, ugyanakkor sajnálatos tényként kell megállapítanunk, hogy az osztrák kormányzat az állami kiadások kevesebb, mint $2 \%$-át fordította a közoktatásra. A népiskolák számának gyarapodása ellenére az országban 5-6000 település volt iskola nélkül, s a tanköteles gyermekeknek is kevesebb, mint fele járt iskolába (Nóbik és Pukánszky, 2015).

Az 1850-es évek végén - amikor a Bach-rendszer válságba jutott - a magyar oktatásügy a Helytartótanács kezébe került, tehát lazult az osztrák kormányzattól való függés. Joggal várhatnánk, hogy az iskolázás ezáltal nagyobb fejlődési ütemet mutasson, azonban csökkent az iskolák látogatottsága, olyannyira, hogy 1863-ban 100.000-rel kevesebb gyermek járt iskolába, mint 1859-ben. Az 1860-as évek első felében ezekből kifolyólag települések százai zárták be népiskolájukat. Ennek a mélypontnak okát minden kétséget kizárólag az osztrák kormányzati felügyelet csökkenésében kell keresnünk (Mészáros, Németh és Pukánszky, 2003. 304. o.).

A szabadságharc leverése után a romhányi tanoda életében is új korszak kezdődött, ugyanis ebben az időben érkezett a településre Bazsó Gábor tanító, aki egy évtizeden keresztül látta el a romhányi gyermekek nevelését. Érkezésének pontos ideje ismeretlen, a fennmaradt források alapján 1849 szeptembere és 1850 júniusa közé tehetjük. ${ }^{7}$ A tanító munkáját a segédtanítók segítették, akik többnyire 1-1 tanéven át tevékenykedtek a községben. Többek között itt dolgozott az 1850-es évek során Arndorfer József, Válent Antal, Kácser Libor, Gyürki Titusz, illetve Magyar Mihály. Az iskola továbbra is egy tanteremből álló triviális tanoda volt, ahol egész napos oktatás folyt, magyar nyelven. A diákok a tanodában vallástant, olvasást, írást, számtant, bibliai történeteket, illetve földrajzot tanultak, de nagy hangsúlyt fektettek a földmúvelés és a szőlészet alapjainak elsajátítására is. Érdekes azonban, hogy a földrajz mint oktatott tantárgy 1856-tól kezdve nem szerepel az iskolai jelentésekben. A tanköteles gyermekek száma az évtized elején, vagyis az 1851/52-es tanévben 160 fő volt, ami az évtized második felére jelentősen csökkent. Az 1857/58-as tanévben csupán 141 tanköteles gyermeket írtak össze a községben. Ezt követően növeke-

7 VPKL Plébániai levéltár, A romhányi r.k. plébánia iratai, Számadáskönyv Romhány, 17691872. 
désnek indult a számuk, az 1858/59-es tanévben 151, az 1859/60-as tanévben pedig már 172 iskolás korú gyermek volt. Más képet kapunk azonban az iskolába járó gyermekek esetében. Az 1850-es évek elején a tanköteleseknek 94,4 \%-a járt iskolába, többnyire rendszertelenül. Az évtized végére azonban ennek aránya romlott, az 1858/59-es tanévben a tankötelesek 93,4 \%-a, az 1859/60-as tanévben pedig már csak 90,6 \%-a látogatta a tanodát. ${ }^{8}$ Mind a tankötelesek, mind pedig az iskolába járók száma jóval meghaladta az 1845-ös rendelet által maximált 100 főt. A Bach-rendszer végére tehát az oktatás színvonalának általános hanyatlása a településen, de a szomszédos Tereskén és Felső-Szátokon is érzékelhetô volt. ${ }^{9}$ Igaz ez az infrastruktúrára is, ugyanis már 1856 tavaszán felmerült a régi iskolaépület lebontása, és egy új tanoda, illetve tanítói lakás építése. ${ }^{10} \mathrm{Ez}$ a terv minden bizonnyal nem valósult meg, melyre az 1860-as években tapasztalt állapotokról következtethetünk.

A provizórium éveiben tehát további hanyatlást figyelhetünk meg. 1860-ra a tanítói lakás állapota annyira leromlott, hogy annak összedőlésétől félve a tereskei tanítóhoz hasonlóan - Bazsó tanító elhagyta hivatalát és Lőrincibe távozott. Ahhoz, hogy a megüresedett kántortanítói állomást a község be tudja töltetni, először a tanítói lakot kellett helyreállítani, vagy újraépíteni. A község ezt a kötelezettséget magára is vállalta, azonban az építkezés mégis nagyon lassan haladt előre. Az új pályázat kiírásának kapcsán megismerjük a kántortanítónak járó jövedelmeket is. Ebben az időben a kántortanító a lakáson és a hozzá kapcsolódó kerten kívül rendelkezett ingatlanbirtokokkal, melyeknek területe a folyamatban lévő tagosítás után 8 holdra egészül ki. Párbérként minden pár után $1 \frac{1}{2}$ pozsonyi mérő rozs, illetve 16 krajcár illette meg, melyhez jött még 15 krajcár stóladíj. Deputátumként kapott fél szalonnát, 50 font sót, 4 font faggyút, 4 icce vajat, 2 kocsi szénát, 12 öl tưzifát. A tandíj címén 10 osztrák értékú forint illette meg. Az ostyasütéshez kántori minőségében 2 pozsonyi mérő búzát kapott. ${ }^{11}$ Láthatjuk tehát, hogy a tanító javadalmazása 1789-hez képest csak minimálisan változott.

A távozott kántortanító helyére 1860-ban Kovács József érkezett, aki az 1860-as évek végéig töltötte be Romhányban ezt a hivatalt. Az 1864/65-ös tanévről szóló jelentésben részletesebb képet kaphatunk az 1860-as évekbeli iskola életéről. A község tanodája továbbra is egy tanteremből álló elemi altanoda volt, ahol a tanulók három részre voltak osztva, első, második és harmadik osztályra. A diákok oktatásáért és neveléséért a kántortanító, illetve a segédtanító feleltek. A kántortanítói javadalmazás 495 osztrák értékû forintot tett ki, melyből 165 forintot készpénzben, 302 forint 86 krajcárt terményben, 27 forint 14 krajcárt

\footnotetext{
8 VPKL Püspöki levéltár, Váci Püspöki Hivatal iratai, Iskolai iratok, Informatio scholaris, 1-4. doboz 1770-1865. Informatio scholaris Romhány, 1851-1860.

9 MNL NML IV-152/b, 120. doboz, 4618/1860.Tereske és Szátok elhanyagolja az iskolát, 1860.

10 MNL NML IV-152/b, 105. doboz, 4370/1856. Iskolaépítés Romhányban, 1856.

11 VPKL Püspöki levéltár, Váci Püspöki Hivatal iratai, Acta Parochiarum, Romhány, 1. doboz 1774-1869, 1640/1860. A romhányi iskolamester és kántor üres álláshelyének betöltésére állás hirdetése és jövedelmeinek előírása, 1860.
} 
pedig az ingatlanbirtokok jövedelme után kapott. A 6-12 éves tankötelesek száma a tanévben 175 fő volt, az iskolai jelentés szerint a tanköteleseknek 100 \%-a járt iskolába, ami feltûnő, hiszen az országos trendeknek teljesen ellentmond. A vizsgált korszakban még egy év, 1899 fordul elo, amelyben szintén 100\% az iskolát látogató gyermekek aránya. Ez arra enged következtetni, hogy Romhányban alapvetően magas az iskola elfogadottsága. Felmerülhet ugyanakkor az is, hogy az iskolai jelentés téves adatot tartalmaz, azonban kontrollforrás hiányában a kérdés nem eldönthető. Ismétlő iskola látogatására - tehát 12-15 év között - a községben 90 gyermek volt kötelezve, azonban ismétlő iskola a faluban nem létezett. A tanügyi jelentés az iskola épületét középszerúnek tünteti fel, azonban erről a következő évben más képet kapunk. ${ }^{12}$ 1865-ben ugyanis a község plébánosa, Kopich Ignác a következő szavakkal jellemezte a tanodát: „, [...]scholam tunc temporis ovili similem in qua scholares ob defectum schamnorum terrae insidere coacti fuerant, $[. .$.$] ", mely szó szerinti fordításban a következőképpen hangzik ,"$ [...] az iskolát, amely abban az időben istállóhoz hasonlított, ahol a tanulók a padoknak hiánya miatt a földön kényszerültek ülni vala, [...] "13 Az iskola épülete tehát külsőleg és belsőleg egyaránt elhanyagolt volt. 1865 augusztusában a plébános a földesurak, a községi elöljárók és a hívek együttes összefogásával belülről felújíttatta az épületet. Az iskola padlóját deszkákkal lefedték, új padokkal, katedrával, feszülettel, új asztalkával és székkel, valamint kemencével rendezték be. ${ }^{14}$ A plébános saját költségén $6 \mathrm{db}$, bibliai eseményeket ábrázoló képet, illetve 14 olvasótáblát adományozott az iskolának. ${ }^{15}$ Még ugyanez év szeptemberében Ehn Bernát egyházkerületi tanfelügyelő iskolalátogatást tartott a községben, melynek során megállapította, hogy a tankötelesek magas száma miatt - kb. 180-an lehettek - szükség van egy másik tanterem felépítésére. Ezt az 1845. évi helytartótanácsi rendelet is előírta, ugyanis maximálisan 100 főt engedett egy tanteremben tanítani. Emellett a település diákjainak más problémával is szembe kellett nézniük. Romhány a XIX. században még 2 részből állt, a Lókos patak folyásától északra helyezkedett el Nagyromhány, délre pedig Kisromhány. Nagyromhányt a község lakosai Falunak, Kisromhány magasabban fekvő részét Dombnak, a lapályos területen fekvőt pedig Pástnak nevezték, s nevezik még ma is. A két településrész között, a Lókos árterén még a XX. század elején is erdős, beépítetlen terület volt. Mivel az iskola épülete a Faluban volt, így a Dombon és a Páston lakó tanulóknak naponta kb. 2 km-es utat kellett megtenniük az iskoláig, valamint az otthonukig. Ez különösen a Lókos áradásakor, az esôs, sáros időszakban - amikor az utak járhatatlanok voltak -, valamint a téli nagy hidegben jelentett problémát. Mivel a lakosság szegénysége miatt a diákok

\footnotetext{
12 VPKL Püspöki levéltár, Váci Püspöki Hivatal iratai, Iskolai iratok, Informatio scholaris, 4. doboz 1860-1865, Táblázat a Romhányi egyházközségben lévő népiskolák állapota iránt az 1865. tanévben.

13 VPKL Plébániai levéltár, A romhányi r.k. plébánia iratai, Historia Domus, II. kötet, 1845-1997.

14 VPKL Püspöki levéltár, Váci Püspöki Hivatal iratai, Acta Parochiarum, Romhány, 1. doboz 1774-1869, 1774/1865. A romhányi iskola felújítása, 1865.

15 VPKL Plébániai levéltár, A romhányi r.k. plébánia iratai, Historia Domus, II. kötet, 1845-1997.
} 
ruházata hiányos volt, így a dombi és a pásti gyermekek a téli időszakban alig jártak iskolába. A tanfelügyelő a probléma orvoslására indítványozta, hogy a község a Dombon építsen egy másik iskolát, a tanítást pedig a kántortanító által felfogadott és eltartott segédtanító végezze. Cserébe viszont a község emelje meg a kántortanító jövedelmét. Ezzel a tervvel tehát megoldódott volna a 60-70 kisromhányi gyermek tanodába járása, valamint a Faluban lévő iskola túlzsúfoltsága is. A község elöljárói és a szolgabíró nem fogadták szívélyesen a tanfelügyelő indítványát. ${ }^{16}$ Csaknem másfél hónappal később a tanfelügyelő ismét Romhányba látogatott az iskola ügyének rendezése céljából. A község elöljárói ekkor már belátták, hogy az új elemi iskola valóban szükséges, viszont az 1865-ös év mostoha viszonyai miatt csak az elkövetkezendő években látták kivitelezhetőnek a felépítését. A tanfelügyelő ekkor javaslatba hozta, hogy amíg a községnek nincs anyagi fedezete az új iskola felépítésére, addig vegyen haszonbérbe egy lakóházat, s rendezze be iskolateremnek. A község erre a célra azonnal ki is bérelte özvegy Balázs Pálné lakóházát, azzal a feltétellel, hogy az iskolában való tanítást a kántor, vagy a segédtanító azért a fizetésért végezze, amennyit jelenleg is kap a községtől. A kántortanító azonban ezt megtagadta, ugyanis a tanulók nagy száma miatt köteles volt ugyan segédtanító tartására, de csak a jelenlegi iskolában, vagy annak szomszédságában. Mivel a Dombon létesítendő iskola távol esett, így csak jóval nagyobb bérért tudott volna segédtanítót fogadni. A község azonban a kántortanítói jövedelem megemelésére továbbra sem volt hajlandó, így kérte Peitler Antal váci püspököt, hogy helyezzen ki egy új tanítót a dombi iskolába, valamint hogy az új tanító fizetéséhez való hozzájárulástól a nehéz anyagi viszonyokra való tekintettel a községet mentesítse. A tanfelügyelő ekkor javasolta, hogy a kántortanítótól vegyék el a párbért, s adják az új tanítónak, valamint a község még 1-2 öl túzifával járuljon hozzá. Ez ellen azonban mind a kántor, mind pedig a plébános tiltakozott, de a kántortanítói jövedelem megcsonkításától a püspök is elzárkózott. A vitás ügy rendezéséig a püspök javasolta, hogy a tanító részére a község ideiglenesen ajánljon meg a lakáson kívül 200-300 osztrák értékú forintot, valamint 1-2 öl tûzifát, majd pedig ha a plébános és a községi elöljáróság megegyezésre jut, akkor újból rendezik a tanítói fizetést. ${ }^{17}$ A község azonban a szúkös anyagi helyzetére hivatkozva az ideiglenes hozzájárulástól is elzárkózott. ${ }^{18}$ Így tehát a dombi iskola megvalósítására még hosszú évtizedeket kellett várni, de az egy tanteremből álló tanoda túlzsúfoltsága is csak évek múlva oldódott meg.

\footnotetext{
16 VPKL Püspöki levéltár, Váci Püspöki Hivatal iratai, Acta Parochiarum, Romhány, 1. doboz 1774-1869, 2290/865. A Romhányban építendő második iskola ügye, 1865.

17 VPKL Püspöki levéltár, Váci Püspöki Hivatal iratai, Acta Parochiarum, Romhány, 1. doboz 1774-1869, 2721/1865. Ismertetés, hogy a romhányi új iskolába kinevezendő tanító kifizetendő béréhez az iskolamesterét hozzá lehet-e kapcsolni, de úgy, hogy ez a közösségi kötelesség megmaradjon, 1865.

18 VPKL Püspöki levéltár, Váci Püspöki Hivatal iratai, Acta Parochiarum, Romhány, 1. doboz 1774-1869, 2932/1865. Romhányban szükséges egy tanító beiktatása, s annak kifejtése, hogy a hívek polgárjogi eszközökkel legyenek bérének fizetésére kényszerítve, 1865.
} 
Pedagógiatörténeti Szemle • 2. évf. 3-4. sz. 20-48. o. • 2016

DOI:10.22309/PTSZEMLE.2016.3.2

\section{ROMHÁNY TANÜGYI HELYZETE A „BOLDOG BÉKEIDŐK” ELSŐ ÉVEIBEN}

Magyarország történetében - s ezzel együtt az oktatásügy történetében is mérföldkövet jelentett az 1867-es kiegyezés, melynek során Ferenc József elismerte az 1848-as törvények nagy részét. Az újjáalakított kormányban a vallásés közoktatásügyi miniszter Eötvös József lett, aki immár hozzáfoghatott az oktatásügy megreformálásához. Lényegében az 1848-ban megalkotott törvényjavaslatához tért vissza. A törvényjavaslat 1868 nyarán került a parlament elé, de csak decemberben szentesítette az uralkodó (Nóbik és Pukánszky, 2015). Ezzel tehát megalkották az 1868. évi XXXVIII. törvénycikket, vagyis az úgynevezett népoktatási törvényt. A törvény kimondta az általános tankötelezettséget, tehát minden 6 és 15 év közötti gyermeknek iskolába kellett járnia, 6-12 év között mindennapi iskolába, 13-15 év között pedig ismétló iskolába, ahol nyáron heti 2, télen pedig heti 5 óra volt a kötelező tanítási idő. Az iskoláztatás elmulasztása esetén a gyermek szüleit pénzbírsággal sújtották, melynek mértéke 50 krajcártól 4 forintig terjedt. Ennek hatástalansága esetén a gyermeket külön gyámság alá is helyezhették. A törvény értelmében a korábbi 3, 4, illetve 5 osztályos elemi iskolák megszúntek, helyettük hatosztályos elemi népiskolák jöttek létre, melyekben a következő tantárgyak kötelező oktatását írták elő: hittan és erkölcstan, írás, olvasás, számtan, nyelvtan, természettan és természetrajz, földrajz, történelem, polgári jog, mezőgazdaság és kertészet, ének, testgyakorlat. Az iskolákat el kellett látni a szükséges taneszközökkel, táblákkal, földgömbökkel, térképekkel, természetrajzi ábrákkal. A tanévnek falvakban legalább 8, városokban legalább 9 hónapig kellett tartania. A törvény 80 fóben maximálta az egy tanító által, egy tanteremben tanítható gyermekek számát. A tanítók személyére vonatkozóan a törvény előírta, hogy csak képezdét végzett, okleveles tanítók taníthatnak. A segédtanítók esetében azonban megengedte, hogy oklevél nélküli, képzésben még résztvevő személyek is oktathassanak. Az elemi iskolai rendes tanító javadalmazására nézve a törvény lakást, $1 / 4$ holdnyi kertet, illetve minimum 300 forint pénzbeli fizetést írt eló. Segédtanítók esetében ez 200 forint volt. Az 1868as népoktatási törvény tehát igyekezett az oktatásügy minden területére hatni. A törvénynek köszönhetően a dualizmus idején nagymértékú fejlődés indult meg a közoktatásban, viszont ahhoz, hogy a törvénybe foglaltak ténylegesen megvalósuljanak, hosszú évtizedekre volt szükség.

A dualizmus első éveiben Nógrád vármegyében az iskolák nagy része felekezeti jellegú volt, községi, társulati, magán és állami iskolák csak elenyésző számban voltak. Az iskolák száma 1869-ben 278 volt, mely 1875-re 23-mal gyarapodott.

A táblázat adatait vizsgálva megállapíthatjuk, hogy a népoktatási törvény életbe lépését követően mind az országban, mind pedig a vármegyében emelkedett az iskolát látogatók aránya. A vármegyei arányok azonban jóval kedvezóbbek az országos adatoknál. Nógrád vármegye esetében az arányokat érdemes lehet tovább vizsgálni aszerint, hogy a tankötelesek közül mennyi 
1. táblázat. A népiskolába járó tankötelesek aránya 1869-1875 között

\begin{tabular}{lllllll}
\hline \multirow{2}{*}{ Tanév } & \multicolumn{2}{l}{ Magyarország } & \multicolumn{4}{l}{ Nógrád vármegye } \\
\cline { 2 - 6 } & Tanköteles & $\begin{array}{l}\text { Népiskolába } \\
\text { járt }\end{array}$ & $\begin{array}{l}\text { Népiskolába } \\
\text { járók aránya }\end{array}$ & Tanköteles & $\begin{array}{l}\text { Népiskolába } \\
\text { járt }\end{array}$ & $\begin{array}{l}\text { Népiskolába } \\
\text { járók aránya }\end{array}$ \\
\hline $1869 / 70$ & n.a & 1111705 & n.a & n.a & 19796 & n.a \\
$1870 / 71$ & 2216375 & 1224480 & $55,25 \%$ & 29548 & 20623 & $69,79 \%$ \\
$1871 / 72$ & 2144758 & 1379671 & $64,33 \%$ & 29489 & 24357 & $82,60 \%$ \\
$1872 / 73$ & n.a & 1443266 & n.a & 29401 & 25292 & $86,02 \%$ \\
$1873 / 74$ & 2139207 & 1497144 & $69,99 \%$ & 27643 & 23668 & $85,62 \%$ \\
$1874 / 75$ & 2124899 & 1491121 & $70,17 \%$ & 27874 & 24983 & $89,63 \%$ \\
\hline
\end{tabular}

gyermek járt elemi és mennyi ismétlő iskolába. Az 1871 és 1874 közötti években a vármegye egészében a 6-12 éves tanköteles gyermekek 91-92 \%-a látogatta az elemi iskolát, majd az 1874/75-ös tanévben ez 95 \%-ra emelkedett. Más volt a kép a 13-15 év közötti, ismétlő iskolára kötelezett gyermekeknél. Az 1871-74 közötti időszakban a 13-15 éves tankötelesek 59-70 \%-a járt ismétlő iskolába, az 1874/75-ös tanévben azonban arányuk 74 \%-ra nőtt. Láthatjuk tehát, hogy az ismétlő iskolák látogatottsága jóval elmaradt az elemi iskolákétól. ${ }^{19}$

Az 1874/75. tanévről a nógrádi járásra vonatkozóan is maradtak fenn statisztikai adataink, melyből megtudjuk, hogy a járásban 3966 tanköteles gyermek volt, akik közül 3455 járt iskolába, tehát 87 \%-uk. A tankötelesek 13 \%-a viszont iskolakerülő volt, de az iskolát látogatóknak is $98 \%$-a csak télen járt. Az iskolakerülő tankötelesek aránya tehát a járásban $3 \%-k a l$ magasabb volt, mint megyei szinten. A járásban kizárólag felekezeti iskolák léteztek, számuk 40 volt, ezekben 41 tanító múködött, tehát egy tanítóra átlagosan 84 diák jutott. A tantermek száma csak 32 volt, melyre átlagosan 94 diák jutott. Ez ellentétben áll az 1868-as népoktatási törvénnyel, ugyanis a törvény szerint egy tanteremben 80 diáknál több nem tanulhat. Tehát a járásra tanterem- és tanítóhiány volt jellemző. A taneszközökre nézve is tapasztalhatunk hiányosságokat. A járás iskoláiban összesen 40 fekete írótábla, illetve 36 olvasótábla volt. Nagyobb volt a hiányosság a természetrajzi és természettani taneszközökből, ugyanis előbbiből 20, utóbbiból csupán 9 darab volt a járás tanodáiban. ${ }^{20}$

A vármegyei tanügyhöz hasonlóan Romhány oktatási helyzete sem a legszebb időszakát élte a dualizmus első éveiben. Az 1867-es esztendő a község tanodájának életében is fontos mérföldkő volt, ugyanis ekkor került segédtanítóként a községbe az ipolysági születésú Trautwein Gyula. A segédtanítóból 1869-ben kántortanító lett, s több mint fél évszázadon át - 1921-ben bekövetkezett haláláig - végezte kiváló szorgalommal és eredménnyel a romhányi gyermekek

19 MNL NML XV-15, 493. tekercs, Nógrádi Lapok, Nógrád vármegye népoktatásának állapota az egyes tanévekben, 1873-1876.

20 MNL NML XV-15, 493. tekercs, Nógrádi Lapok és Honti Híradó, 4. 17. sz. Nógrád megye népoktatási állapotának járások szerinti kimutatása (1876.04.23) 
oktatását és nevelését, továbbá a kántori feladatok ellátását. ${ }^{21}$ Az ezt követő évekből sajnos nincsenek adataink az iskola életére vonatkozóan azon kívül, hogy 1871 novemberében a népoktatási törvény elő́rásának megfelelően a községben is megszervezték az ismétlő iskolai oktatást. ${ }^{22}$ Az évtized közepe viszont kulcsfontosságú volt a község tanodájának történetében. 1874-ben a községi pénztár 800 forintnyi maradvánnyal rendelkezett, melyet egy második tanterem létesítésére kívántak fordítani. Égetően nagy szükség is volt erre, ugyanis kiindulva abból, hogy az 1864/65-ös tanévben 175 elemi iskolai tanköteles volt a településen, számuk a későbbi években sem lehetett sokkal kevesebb. Az 1868. évi népoktatási törvény viszont csak 80 gyermeket engedett egy tanteremben tanítani, tehát az egyetlen tanteremből álló iskola, és az egyetlen tanító már régóta nem szolgálta ki az igényeket. Az 1865-ös kudarc után, 1874 nyarán végre felépítették a második iskolai tantermet, melyhez tanítói szobát is építettek, továbbá ezeket padokkal és bútorokkal is berendezték. A tanulók nagy száma miatt újból megszervezték a községben a segédtanítói állomást, a községtől járó évi 150 forint fizetésért és a kántortanító által nyújtott ellátásért. ${ }^{23}$ A Néptanítók Lapjában olvashatunk is segédtanítói álláshirdetéseket 1874 júliusából, illetve decemberéből, valamint 1875 augusztusából. 1874-ben a 150 forint évi fizetésen és a kántor által biztosított lakáson és élelmezésen kívül 6 forint havi mellékjövedelmet is ígértek a segédtanítónak, viszont elvárták tôle az 1. osztály tanítását, illetve az ismétlő iskolai oktatást, továbbá a kántori feladatokban való segédkezést (Néptanítók Lapja 7. 14. és 24. sz.). 1875-ben mellékjövedelmet már nem ígértek neki (Pályázatok (1875.09.30). Néptanítók Lapja 8. 18. sz. 325. o.). Az 1874/75-ös tanévben Minke Béla, az 1875/76-os tanévben pedig egy Szrnka vezetéknevú segédtanító múködött a községben. ${ }^{24}$

Összességében véve elmondhatjuk, hogy az 1870-es évek elején az oktatásügy a vármegyében és a településen egyaránt zavaros időszakát élte, ugyanis a sorozatos természeti csapások, járványok nem kedveztek a még gyerekcipőben járó népoktatási reform kibontakozásának. A korabeli lakosság egy része nem szívesen járatta gyermekét iskolába, mert igyekezett a gyermeket munkára fogni - főleg a nyári időszakban. Télen viszont a meleg ruházat hiánya akadályozta sokszor az iskola látogatását. Az iskolakerülésért kiszabandó pénzbüntetés sem mindig váltotta ki hatását, ugyanis a teljesen elszegényedett lakosság nem tudta azt kifizetni, hiszen sokszor a megélhetésért kellett küzdenie. ${ }^{25}$ A tanítók

\footnotetext{
21 VPKL Püspöki levéltár, Váci Püspöki Hivatal iratai, Iskolai iratok, Schola, Romhány 18951950, 1. doboz, 812/915. Trautwein Gyula kántortanító a Wodianer-féle ösztöndíjért folyamodik, 1915.

22 VPKL Püspöki levéltár, Váci Püspöki Hivatal iratai, Iskolai iratok, Informatio scholaris , 6. doboz 1877-1883, 166/1877. A romhányi alesperesi kerületben létező elemi iskolák állapotát föltüntető jelentés az 1877. évi iskolai évről.

23 VPKL Plébániai levéltár, A romhányi r.k. plébánia iratai, Historia Domus, II. kötet, 1845-1997. 24 VPKL Plébániai levéltár, A romhányi r.k. plébánia iratai, Historia Domus, II. kötet, 1845-1997.

25 MNL NML XV-15, 493. tekercs, Nógrádi Lapok és Honti Híradó, 5. 10. sz. Tanügy. Népnevelés akadályai (1877.03.11)
} 
számánál megállapíthatjuk, hogy folyamatos tanítóhiány volt, számuk 1873-tól kezdve csak lassan emelkedett. A taneszközök tekintetében szintén hiányosságok tapasztalhatók ebben az időszakban. Például az 1871/72. tanévben a vármegye 297 iskolájában csak 295 írótábla, illetve 255 olvasótábla volt, ami azt jelenti, hogy voltak iskolák, ahonnan ezek hiányoztak. ${ }^{26}$ Hasonló volt a helyzet a többi taneszközzel is, bár számuk az idő előrehaladtával folyamatosan gyarapodott. A népoktatási törvény kötelezővé tette, hogy a tanítók egyletekbe szerveződjenek, s ezáltal előmozdítsa a tanítók szakmai szerveződését (Nóbik, 2006. 44. o.). Ez a rendelkezés az ország más területeihez hasonlóan Nógrád vármegye tanügyi helyzetére mindenképpen serkentőleg hatott, ugyanis 1874 januárjában megalakult a Nógrádmegyei Tankerületi Tantestület, melynek legfőbb feladata az iskolaügy szabályozása, illetve egységes rendszerbe foglalása volt (Pacséri, 1900. 8. o.).

\section{Az OKTATÁS HELYZETE A DUALIZMUS FÉNYKORÁBAN}

Tisza Kálmán miniszterelnökségének idején (1875-1890) a dualizmus virágkorát élte, ugyanis rohamosan fejlődött a gazdaság és az infrastruktúra, de a politikai életre is a stabilitás volt jellemző. Az oktatásügyet a népoktatási törvény rendelkezéseinek megvalósítása, illetve olykor pontosítása jellemezte. A törvény rendelkezései lassan ugyan, de kezdték éreztetni hatásukat. Az 1868-as népoktatási törvény rendelkezett a felettes iskolai hatóságokról, a községi és az állami iskolák fölé megszervezték az iskolaszéket, amely egy 9 tagból álló, választott testület volt. Tagjait 3 évre választották, feladatuk pedig a tanítók, illetve segédtanítók választása, az iskolák múködésének és a törvényi rendelkezések betartásának ellenőrzése volt. Emellett az iskolaszék gondoskodott az iskolai épületek esetleges felújításáról, a taneszközök beszerzéséről, döntött az iskolát érintő ügyekben, s felügyelte a vizsgák menetét. Továbbá kapcsot képezett az iskolák, illetve a tankerületi iskolatanács között. 1868-ban az iskolaszékek és a tanfelügyelőségek felállítását a felekezeti iskolákra nem terjesztették ki, ez majd csak az 1876. évi XXVIII. törvénycikk értelmében történt meg. Innentől kezdve tehát a községi iskolák felett a községi iskolaszék, a felekezeti iskolák felett pedig a felekezeti iskolaszék állt. 1879-től minden népiskolában - a nemzetiségiekben is - kötelező tantárgyként vezették be a magyar nyelvet (Nóbik és Pukánszky, 2015).

Az 1876-os esztendő Romhány tanodájának életében baljós kimenetelú volt, ugyanis a sorozatos természeti csapások miatt a község nem tudta tovább vállalni a segédtanítóak járó évi 150 forint fizetését. ${ }^{27}$ Ezzel párhuzamosan a tankötelesek száma is erősen csökkent, így a segédtanítói állomást beszüntették, a hat osztály két tanteremben való tanítása, illetve az ismétlő iskolások tanítása egymagára Trautwein Gyula kántortanítóra hárult. Mindezek mellett 1876 tava-

26 MNL NML XV-15, 493. tekercs, Nógrádi Lapok, 1. 1. sz. Tanügy (1873.01.01)

27 VPKL Plébániai levéltár, A romhányi r.k. plébánia iratai, Historia Domus, II. kötet, 1845-1997. 
szán himlőjárvány miatt az iskolát 2 hétre be kellett zárni. ${ }^{28}$ A községi népiskola ezen vészterhes időszakáról meg is jelent egy pikírt hangvételú írás a Nógrádi Lapok hasábjain Nyilassy Ferenc tollából, aki a következő szavakkal illette a község oktatásügyét: „[... [ társadalmi mozzanatról Romhányban írni annyit tesz, mint a vaknak a szín különbféleségeit magyarázni,[... ]. A mostani gyermeknemzedék számára állitottunk ugyan egy sok költségbe kerülő elemi népiskolát, fel is szereltük a szükséges taneszközökkel, de nem gondoskodtak tanitó-eröről, pedig e nélkül minden ide forditott tőke holt vagyont képez [...]. Ne hidje tehát községünk elöljárósága, hogy az iskola épületáldozatával befejezte a növelés és müveltség iránt tartozó kötelességeit; hanem menjen tovább, szerezzen még legalább két tanitó állomást a fennálló törvény értelmében. [...]"29 Nyilassy Ferenc ezeket a sorokat nyilván tájékozatlanságból írta, ugyanis csak a második tanteremről volt tudomása, a segédtanítói állás szervezéséről nem, hiszen azt ekkorra már beszüntették. Nyilassy tájékozatlansága Kis Miklós községi bíró válaszából is kitúnik, aki a következő sorokkal védte meg községe iskoláját: „[...] más részről pedig az iskolát oly szánandó siralmas állapotban feltünteti; pedig ha kirándulási alkalmával az iskola iránti érdekeltségét, akár az elöadások, akár a jólsikerült vizsgának csak egyszeri meglátogatása által is tanusította volna, meggyöződhetett, miszerint falusi elemi iskolánk nem nevel ugyan pápaszemes jogtudorokat, világboldogitó állam bölcsészeket, mindenhez értő nemzetgazdákat, hanem igen is az 1868. 38. t.cz. által elöírt ismeretekben oktatott polgárokat, és pedig az illető hatóság megelégedését kiérdemelt sikerrel. [...]"30 A községi bíró soraiból látjuk tehát, hogy a község igyekezett volna az 1868. évi népoktatási törvény rendelkezéseinek megfelelni, viszont anyagi helyzete miatt ez igen nagy nehézségekbe ütközött. Mint korábban említettük, 1876-tól az oktatás ismét egyedül a kántortanítóra, Trautwein Gyulára hárult, aki a kántori feladatok mellett az oktatást is a körülményekhez képest kiváló színvonalon végezte. Munkájáért 1877 áprilisában az egyházmegyei tanfelügyelőtől dicséretet is kapott, de 1880-ban is a romhányi iskolát hozta fel követendő példának a többi község számára. ${ }^{31}$ A tankötelesek és az iskolát látogató gyermekek arányát szemléltető táblázatot vizsgálva megállapíthatjuk, hogy mind az országos, mind vármegyei viszonylatban fokozatosan emelkedett az iskolába járó tankötelesek aránya 1875-1880 között. A 2. táblázatból láthatjuk azt is, hogy az 1870-es évek végén Romhányban is fokozatosan emelkedett a tankötelezettek száma, az 1876/77-es tanévben 136, az 1877/78-as tanévben 150, az 1878/79-es tanévben pedig 160 volt. Az iskolát látogatók aránya azonban nem mutatott olyan növekvő tendenciát, mint az ország, vagy a vármegye egészében.

\footnotetext{
28 MNL NML XV-15, 493. tekercs, Nógrádi Lapok és Honti Híradó, 4. 21. sz. Kis Miklós levele (1876. 05.16)

29 MNL NML XV-15, 493. tekercs, Nógrádi Lapok és Honti Híradó, 4. 20. sz. Nyilassy Ferenc levele (1876.05.11)

30 MNL NML XV-15, 493. tekercs, Nógrádi Lapok és Honti Híradó, 4. 21. sz. Kis Miklós levele (1876.05.16)

31 VPKL Püspöki levéltár, Váci Püspöki Hivatal iratai, Iskolai iratok, Informatio scholaris, 6. doboz 1877-1883, Informatio scholaris Districtus Romhány, 1878-1880.
} 
2. táblázat. A népiskolába járó tankötelesek aránya 1875-1880 közöt

\begin{tabular}{|c|c|c|c|c|c|c|c|c|c|}
\hline \multirow{2}{*}{ Tanév } & \multicolumn{4}{|c|}{ Magyarország } & \multicolumn{3}{|c|}{ Nógrád vármegye } & \multicolumn{2}{|c|}{ Romhány község } \\
\hline & Tanköteles & $\begin{array}{l}\text { Népiskolába } \\
\text { járt }\end{array}$ & $\begin{array}{l}\text { Népiskolába } \\
\text { járók aránya }\end{array}$ & Tanköteles & $\begin{array}{l}\text { Népiskolába } \\
\text { járt }\end{array}$ & $\begin{array}{l}\text { Népiskolába } \\
\text { járók aránya }\end{array}$ & Tanköteles & $\begin{array}{l}\text { Iskolába } \\
\text { járt }\end{array}$ & $\begin{array}{l}\text { Iskolába } \\
\text { járók aránya }\end{array}$ \\
\hline$\overline{1875 / 76}$ & 2129597 & 1507031 & $70,77 \%$ & 26260 & 20962 & $79,82 \%$ & n.a & n.a & n.a \\
\hline $1876 / 77$ & 2127950 & 1559636 & $73,29 \%$ & 27204 & 22035 & $81,00 \%$ & 136 & 104 & $76,47 \%$ \\
\hline $1877 / 78$ & 2117192 & 1625235 & $76,76 \%$ & 27452 & 22330 & $81,34 \%$ & 150 & 135 & $90,00 \%$ \\
\hline $1878 / 79$ & 2114864 & 1644803 & $77,77 \%$ & 28025 & 23360 & $83,35 \%$ & 160 & 142 & $88,75 \%$ \\
\hline $1879 / 80$ & 2097490 & 1619692 & $77,22 \%$ & 27529 & 24413 & $88,68 \%$ & n.a & n.a & n.a \\
\hline
\end{tabular}

Megfigyelhetjük azt is, hogy az 1870-es évek második felében a romhányi tankötelesek száma az 1850-es évek végének szintjére esett vissza, sőt 1876/77-ben még az alá. A tankötelesek alacsony számát az 1860-as évek végének különösen magas gyermekhalandóságával magyarázhatjuk. A ténylegesen iskolába járó gyermekek száma is növekedést mutatott, míg az 1876/77-es tanévben a tanköteleseknek csak 76,4 \%-a járt iskolába, az 1877/78-as tanévben már 90 \%-a, az 1878/79-es tanévben pedig 88,7 \%-a. Az iskolába járók aránya tehát csak az 1876/77. tanévben maradt el a vármegye egészében tapasztalható aránytól, ugyanis az 1876/77-es tanévben a tanköteleseknek 81 \%-a, az 1879/80-as tanévben pedig 88,6 \%-a látogatta az iskolát. Az 1876/77-es tanévben a romhányi iskolába járók alacsony arányát a különféle betegségekkel, hanyagsággal, illetve ruhahiánnyal magyarázhatjuk. Sok esetben a többgyermekes családoknál a gyermekek felváltva jártak iskolába, mert nem volt elegendő ruha. A ruhahiány mint mulasztási ok a későbbi években is gondot okozott a községben, s a távolság miatt főként a Dombon lakó gyermekeket akadályozta az iskolába járásban. Az 1876/77-es iskolai jelentésben megfigyelhetjük, hogy az iskolát látogatók között különösen kevesen voltak a fiúk, alig több mint feleannyian jártak iskolába, mint a lányok. Ebből arra következtethetünk, hogy a fiúkat főleg az idősebbeket - a szülők tudatosan tartották távol az iskolától, ugyanis a gyermeket a nagy szegénység miatt inkább dolgozni küldték. A tanulók az iskolában hittant, bibliai történeteket, írást, olvasást, számtant, földrajzot, természetrajzot, történelmet és éneket tanultak. Taneszközök terén az iskola ebben az időszakban a Bárány Ignác-féle olvasótáblákkal, Európa és Magyarország falitérképével, természetrajzi ábrákkal, természettani eszközökkel, számológéppel vagy más néven abakusszal, földgömbbel, illetve az írás tanításához nagy iskolatáblával rendelkezett. Tankönyvként a Szent István Társulat által kiadott tankönyveket használták. Az ismétlő iskolára vonatkozóan csak az 1876/77-es tanévről van adatunk, ekkor 74 tanuló látogatta. ${ }^{32}$ Az évtized legvégén azonban más községekhez hasonlóan Romhányban is problémát jelentett az ismétlő iskolák látogatottságának hanyagolása, ugyanis a község nem akart ezért külön fizetést adni a tanítónak. Ennek következtében 1879-ben a tankerületi felügyelő utasította a plébánosokat, hogy ha a községek erre továbbra sem hajlandóak,

32 VPKL Püspöki levéltár, Váci Püspöki Hivatal iratai, Iskolai iratok, Informatio scholaris , 6. doboz 1877-1883, Informatio scholaris 1877-1880. 
akkor a szolgabíró, illetve a vármegyei Közigazgatási Bizottság elé terjesszék az ügyet. A tanítóknak ugyanakkor meghagyta, hogy ha külön tiszteletdíjat az ismétlő iskolai tanításért nem kapnak, akkor sem szabad az oktatást megtagadni, ugyanis az ismétlő iskola funkciója az, hogy az elemi iskolában megszerzett ismereteket a diákok elmélyítsék, emlékezetükben megtartsák. ${ }^{33}$

Romhány 1870-es évekbeli tanügyének tárgyalásakor szükséges néhány szót szólnunk a község izraelita vallású gyermekeinek oktatásáról is. Az 1880as népszámlálás szerint a település lakosságának csupán 3,5\%-a volt zsidó, tehát számuk igen elenyésző volt. Egy 1878-ban kelt összeírásból megtudjuk, hogy az 1877/78-as tanévben Romhányban 16 izraelita tanköteles gyermek volt. Számuk csekélységénél fogva nem volt izraelita felekezeti iskola, a gyermekek magániskolában, illetve magányos zugiskolában tanultak. A diákok oktatását két tanító végezte, Graf Sámuel, illetve Stuko Sámuel. A Schwaiczer és Rosenberg gyermekeket magániskolában tanította Graf Sámuel, a többi 7 gyermek pedig Stuko Sámuel tanítványa volt, akik zugiskolában tanultak. ${ }^{34}$ Az izraelita gyermekeknek - bár magániskolában tanultak - ugyanazokat a tantárgyakat, és ugyanannyi évig kellett tanulniuk, mint a rendes elemi iskolába járó tanköteleseknek. ${ }^{35}$ A zugiskolákat az 1880-as évek elején sorra betiltották, s 1883-ban már csak egyetlen zugiskola maradt Nógrád vármegyében, mégpedig Szirákon. ${ }^{36}$

Az 1870-es évek végének tanügyi problémái átnyúltak az 1880-as évtized elejére is. Továbbra is általános problémát jelentett az ismétlő iskolák hanyagolása. Egy 1880-ban kelt újságcikk részletesen be is számol a probléma okairól. A lakosság az intézményt továbbra is haszontalannak tartotta, jelentőségét nem ismerte fel. Elegendőnek tartották, hogy az elemi iskola 6 osztályában a gyermek megtanult számolni, írni, olvasni, elsajátította a hittan alapjait, illetve még néhány alapvető ismeretet. Innentől kezdve viszont a szülők a gyermek munkaerejét kívánták használni, a megszerzett ismeretek ismétlését - tehát az ismétlő iskolát - feleslegesnek tartották. Emellett a tanítók hozzáállásával is sok esetben probléma volt, ugyanis az ismétlő oktatást délután tartották, ráadásul szombaton, illetve vasárnap. A vasárnapi oktatás a kántortanítókra az istentisztelet miatt még nagyobb terhet rótt, így sokszor lelkesedés nélkül végezték tanítást. A bajt csak tetézte, hogy a gyermekek is igen rendszertelenül látogatták az ismétlő iskolákat, sok esetben minden második, harmadik alkalommal. A rengeteg mulasztás szintén akadályozta a sikerességet. ${ }^{37}$ Az ismétlő

\footnotetext{
33 VPKL Püspöki levéltár, Váci Püspöki Hivatal iratai, Iskolai iratok, Informatio scholaris , 6. doboz 1877-1883, 2076/1879. Informatio scholaris Districtus Romhány, 1879.

34 MNL NML VI-501, 1. doboz, Vegyes tanfelügyelői iratok, 46/878. Kimutatás a nógrádi járás területén lévő izraelita tankötelesekről, 1878.

35 MNL NML XV-15, 494. tekercs, Nógrádi Lapok és Honti Híradó, 5. 1. sz. A tanügy köréből (1877.01.07)

36 MNL NML XV-15, 495. tekercs, Nógrádi Lapok és Honti Híradó, 9. 18. sz. Nógrádmegye közigazgatási bizottsági ülése (1883.05.01)

37 MNL NML XV-15, 494. tekercs, Nógrádi Lapok és Honti Híradó, 8. 2. sz. Tanügy. Az ismétlő iskola akadályai (1880.01.11)
} 
iskolázás a vármegye egészéhez hasonlóan Romhányban is gyenge lábakon állt, ugyanis, - bár a tanfelügyelő több ízben is figyelmeztette a szülőket a gyermek iskolába járatására - a szülők nagy része ezért plusz tandíjat nem volt hajlandó fizetni, részben szegénységük, részben hanyagságuk okán. ${ }^{38}$ Az évtized vége felé azonban javult a kép, ugyanis az 1887/88-as tanévben az ismétlő iskolára kötelezetteknek 85 \%-a, az 1888/89-es tanévben pedig 82 \%-a járt iskolába. Ez az arány tehát jónak mondható, hiszen egyrészt jóval meghaladta a vármegyei arányt, másrészt pedig Romhányhban az elemi iskolára kötelezetteknek is 90 \%-a látogatta az említett tanévekben az iskolát. ${ }^{39}$ A táblázatot vizsgálva megállapíthatjuk, hogy az országban az iskolák látogatottságának aránya szerény mértékben emelkedett, az 1884/85-ös tanévtől kezdve a tanköteleseknek 80\%-a járt iskolába. Ezzel szemben Nógrád vármegye más képet mutatott, ugyanis az elemi iskolák látogatottságának aránya az 1880-as évek elejétől kezdve fokozatosan csökkent. Ez a csökkenő tendencia az évtized közepén megállt, majd szerény növekedés és stagnálás után az 1888/89-es tanévre elérte a 86\%-ot. A táblázatot vizsgálva megállapíthatjuk, hogy az iskolát látogató tankötelesek aránya még mindig elmaradt az évtized elején tapasztalt aránytól. ${ }^{40}$

3. táblázat. A népiskolába járó tankötelesek aránya 1880-1889 között

\begin{tabular}{|c|c|c|c|c|c|c|c|c|c|}
\hline \multirow{2}{*}{ Tanév } & \multicolumn{3}{|c|}{ Magyarország } & \multicolumn{3}{|c|}{ Nógrád vármegye } & \multicolumn{3}{|c|}{ Romhány község } \\
\hline & Tanköteles & $\begin{array}{l}\text { Népiskolába } \\
\text { járt }\end{array}$ & $\begin{array}{l}\text { Népiskolába } \\
\text { járók aránya }\end{array}$ & Tanköteles & $\begin{array}{l}\text { Népiskolába } \\
\text { járt }\end{array}$ & $\begin{array}{l}\text { Népiskolába járók } \\
\text { aránya }\end{array}$ & Tanköteles & $\begin{array}{l}\text { Iskolába } \\
\text { járt }\end{array}$ & $\begin{array}{l}\text { Iskolába } \\
\text { járók aránya } \\
\text { (elemi és ismétlő) }\end{array}$ \\
\hline $1880 / 81$ & 2119676 & 1656337 & $78,14 \%$ & 27204 & 24719 & $90,87 \%$ & n.a & n.a & n.a \\
\hline $1881 / 82$ & 2189672 & 1691922 & $77,27 \%$ & 28115 & 24879 & $88,49 \%$ & 262 & n.a & n.a \\
\hline $1882 / 83$ & 2232891 & 1742668 & $78,05 \%$ & 29046 & 24731 & $85,14 \%$ & 254 & n.a & n.a \\
\hline $1883 / 84$ & 2250062 & 1785893 & $79,37 \%$ & 30262 & 24538 & $81,09 \%$ & n.a & n.a & n.a \\
\hline $1884 / 85$ & 2283361 & 1827141 & $80,02 \%$ & 30790 & 25435 & $82,61 \%$ & n.a & n.a & n.a \\
\hline $1885 / 86$ & 2317875 & 1864638 & $80,45 \%$ & 31323 & 26402 & $84,29 \%$ & n.a & n.a & n.a \\
\hline $1886 / 87$ & 2373334 & 1925852 & $81,15 \%$ & 32847 & 27454 & $83,58 \%$ & n.a & n.a & n.a \\
\hline $1887 / 88$ & 2403507 & 1946246 & $80,98 \%$ & 33016 & 27594 & $83,58 \%$ & 255 & 226 & $88,63 \%$ \\
\hline $1888 / 89$ & 2466243 & 2009929 & $81,50 \%$ & 33046 & 28479 & $86,18 \%$ & 243 & 214 & $88,07 \%$ \\
\hline
\end{tabular}

Romhány esetében a tankötelesekre, illetve az iskolát látogatókra nézve az 1880-as évek első feléről nem, illetve csak nagyon kevés statisztikai adattal rendelkezünk. 1881-ben 262 tanköteles gyermek volt, az elemi és az ismétlő iskolára kötelezetteket egybevéve. ${ }^{41} \mathrm{Az}$ 1882/83-as tanévre ez 254-re csökkent,

38 VPKL Püspöki levéltár, Váci Püspöki Hivatal iratai, Iskolai iratok, Informatio scholaris, 6. doboz 1877-1883, 2222/1880. Jegyzőkönyv a romhányi alesperesi kerületben megejtett iskola látogatásról az 1879/80. iskolai évben.

39 MNL NML XV-15, 496. tekercs, Nógrádi Lapok és Honti Híradó, 18. 11. sz. Tanügy. Komjáthy Anzelm királyi tanácsos és királyi tanfelügyelő jelentése (1890.03.16)

VPKL Püspöki levéltár, Váci Püspöki Hivatal iratai, Iskolai iratok, Informatio scholaris, 7-8. doboz 1884-1892, A romhányi népiskoláról szóló évi jelentés, 1888-1889.

40 MNL NML XV-15, 496. tekercs, Nógrádi Lapok és Honti Híradó, 16. 33. sz. Alispáni jelentés (1888.05.30)

41 MNL NML XV-15, 494. tekercs, Nógrádi Lapok és Honti Híradó, 9. 34. sz. Közigazgatási bizottsági ülés (1881.08.13)

A Nógrádi Lapok 1881. évi 34. számában olvasható, hogy a romhányi iskolának 262 tanulója van, mely adat minden bizonnyal a tanköteles gyermekek számát jelenti, ugyanis az 1880-as évek 
melyből 150-en jártak elemi iskolába, vagyis az elemi iskolára kötelezettek 85,7\%a. ${ }^{42}$ Ez tehát még mindig elmaradt az ugyancsak csökkenő tendenciát mutató vármegyei szinttől.

Mivel az iskolában még mindig csak egyetlen tanító múködött - hiszen 1876-ban a segédtanítói állomást beszüntették -, így a tanulók magas száma miatt egyre égetőbb szükséggé vált a segédtanítói állás újbóli rendszeresítése. Ennek fontosságát az egyházmegyei tanfelügyelő már 1878-tól kezdve folyamatosan hangsúlyozta, viszont a lakosság elszegényedése miatt ez ekkoriban kivitelezhetetlennek bizonyult. 1881 nyarán azonban a romhányi segédtanító ügye Nógrád Vármegye Közigazgatási Bizottságának asztalára került. Az augusztus 13-án tartott ülésen vita bontakozott ki arról, hogy a segédtanítói állomás rendszeresítéséhez a községnek, vagy pedig a helybeli hitfelekezetnek kötelessége hozzájárulni. A bizottság ekkor határozatot hozott arról, hogy az ügyben először a községi képviselőtestülettel kell tárgyalni, s meg kell ismerni álláspontját. ${ }^{43}$ A község képviselőtestülete a hozzájárulást azonban megtagadta, anyagi fedezet hiányában. Végül a Közigazgatási Bizottság novemberi ülésén hozott határozata értelmében a község képviselőtestületének és a helybeli iskolaszéknek együttmúködve kell a segédtanítói állást megszervezni. ${ }^{44}$ Ennek eredményeként 1882 őszétől ismét rendszeresítették a segédtanítói állomást, ám 1874-től eltérően a községtől csak évi 100 forint, valamint a kántortanítótól járó élelmezés fejében. ${ }^{45}$ A Néptanítók Lapjában olvasható álláshirdetésből megtudjuk azt is, hogy az egyik helyi földbirtokos további 150 forintot, továbbá a szünidőre teljes ellátást kínált a leendő segédtanítónak, amennyiben a tanító elvállalja - az evangélikus - család gyermekeinek tanítását is (Pályázatok (1882.09.09). Néptanitók Lapja, 15. 36. sz. 572.). Az 1882/83-as tanévben a községben segédtanítóként múködött Kerekes József, majd pedig egy Frei vezetéknevú tanító. A segédtanító fizetése, illetve a községi hozzájárulás mértéke még a későbbi években is elégedetlenkedést szült a településen, mivel a római katolikus iskolában múködő segédtanító fizetését felekezeti hovatartozásra való tekintet nélkül, lélekszám arányában vetették ki a lakosságra. Ezt 1889-ben Laszkáry Gyula romhányi földbirtokos meg is fellebbezte. ${ }^{46}$ Segédtanítót tehát a korábban ismertetett javadalmazással alkalmaztak a faluban. Az 1882/83-as tanévről szóló jelentésben a rendes tanító javadalmazására nézve is találunk adatokat. A kántortanító párbér fejében a 285 pár után kapott 142 és 1⁄2 pozsonyi mérő rozst, továbbá minden pár után 25 krajcár készpénzt. Emellé járt még

végén az összes tankötelezett száma 240-255, az iskolába járóké pedig 216-226 fő között váltakozott, az ismétlő iskolásokkal együtt.

42 VPKL Püspöki levéltár, Váci Püspöki Hivatal iratai, Iskolai iratok, Informatio scholaris, 6. doboz 1877-1883, Informatio scholaris 1882/83

43 MNL NML XV-15, 494. tekercs, Nógrádi Lapok és Honti Híradó, 9. 34. sz. Közigazgatási bizottsági ülés (1881.08.13)

44 MNL NML XV-15, 494. tekercs, Nógrádi Lapok és Honti Híradó, 9. 47. sz. Közigazgatási bizottsági ülés (1881.11.20)

45 VPKL Plébániai levéltár, A romhányi r.k. plébánia iratai, Historia Domus, II. kötet, 1845-1997.

46 MNL NML V-302, 1. doboz, Képviselőtestületi jegyzőkönyvek 1886-1897. 1/89. kgy. hat. 
stólajövedelem címén 50 forint, deputátumok címén 12 öl fa, valamint kisebb adományok összesen 34 forint értékben. A 16 hold föld után 100 forint telekjövedelem is megillette oot. ${ }^{47}$ Érdemes ezt összevetnünk a kántortanító 1860 -as évekbeli javadalmazásával. A tankötelesek és az iskolát látogatók számát megvizsgálva megállapíthatjuk, hogy az évtized legvégén, az 1887/88, illetve az 1888/89-es tanévben a romhányi tanköteles gyermekek 88 \%-a járt iskolába, s mint korábban említettük a 6-12 éves tanköteleseknek 90\%-a, a 13-15 éves tanköteleseknek pedig 85, illetve 82 \%-a látogatta a tanodát. Ez a 88\%-os arány tehát meghaladta mind az országos viszonylatban tapasztalt $81 \%$-ot, mind pedig a vármegyében tapasztalt 83-86\%-ot. Az oktatást továbbra is a falu dicséretes kántortanítója, Trautwein Gyula, valamint Szvetelszky Emil és Schrenker Géza segédtanítók végezték. ${ }^{48}$

1888-ban azonban újabb sorscsapás érte a romhányi népiskolát, ugyanis az április 23-án - a tervezett s végül elmaradt tanév végi vizsga napján - kiütött tû́zvész során a templommal, a parókiával, a községházával és még kb. 50 házzal együtt az iskola épülete is leégett. ${ }^{49}$

Mivel a tanoda épülete a község tulajdonát képezte, így helyreállítása a községre hárult. Az épületek helyreállítására a biztosító 1100 forintot állapított meg. További 350 forint ráfizetéssel az iskolát a jegyzői lakkal együtt a korábbi zsindelytető helyett cseréptetővel látták el, továbbá az ajtók és ablakok javítására is fordítottak az összegből. ${ }^{50}$ Emellett a község elöljárósága felségfolyamodványt is benyújtott, melynek köszönhetően őfelsége Ferenc József a romhányi tûzkárosultaknak 500 forintot adományozott. Ebből az összegből 75 forintot az iskola ablakainak, ajtóinak, padjainak javítására, továbbá a tönkrement tanszerek pótlására fordítottak. ${ }^{51}$ A tûzvész azonban évekre megpecsételte az iskola sorsát, ugyanis még az 1890/91. tanévről szóló iskolai jelentés is hiányos taneszközökről számol be, amelyek ekkor semmisültek meg. ${ }^{52}$ Az iskolaszék azonban még 1893 nyarán is azzal a panasszal fordult a község képviselőtestületéhez, hogy az iskola mellett nincs árnyékszék és a tantermek sincsenek megfelelő eszközökkel ellátva. A képviselőtestület még ebben az évben saját költségén felállíttatott egy árnyékszéket a tanoda mellé, valamint elkészíttette az iskola téli ablakait. Mindezek mellett az új tanévre elegendő szivaccsal és krétával is ellátta azt. ${ }^{53}$

\footnotetext{
47 VPKL Püspöki levéltár, Váci Püspöki Hivatal iratai, Iskolai iratok, Informatio scholaris, 6. doboz 1877-1883, Informatio scholaris 1882/83.

48 VPKL Püspöki levéltár, Váci Püspöki Hivatal iratai, Iskolai iratok, Informatio scholaris, 7-8. doboz 1884-1892, A romhányi népiskoláról szóló évi jelentés, 1888-1889.

49 VPKL Püspöki levéltár, Váci Püspöki Hivatal iratai, Iskolai iratok, Informatio scholaris, 7. doboz 1884-1888, 4078/888. A romhányi kerület alesperese indokolja az évvégi vizsgálat elmaradását a romhányi népiskolában, 1888 .

VPKL Plébániai levéltár, A romhányi r.k. plébánia iratai, Historia Domus, II. kötet, 1845-1997.

50 MNL NML V-302, 1. doboz, Képviselőtestületi jegyzőkönyvek 1886-1897. 7/89. kgy. hat.

51 MNL NML V-302, 1. doboz, Képviselőtestületi jegyzőkönyvek 1886-1897. 9/88. kgy. hat.

52 VPKL Püspöki levéltár, Váci Püspöki Hivatal iratai, Iskolai iratok, Informatio scholaris, 8. doboz 1889-1892, 3710/890. Évi jelentés a romhányi római katholikus népiskoláról, 1889/90. évre.

53 MNL NML V-302, 1. doboz, Képviselőtestületi jegyzőkönyvek 1886-1897. 12/93. kgy. hat.
} 


\section{NÉPISKOLÁNK ÉLETE A SZÁZADFORDULÓ IDŐSZAKÁBAN}

A századforduló magyar oktatásügyét továbbra is az 1868-as népoktatási törvény határozta meg. Időnként azonban szükség volt a törvény egyes rendelkezéseinek pontosítására. A felekezeti iskolákban tanítók fizetésére nézve az 1868. évi törvény nem rendelkezett, csupán az állami és a községi iskolákban tanítókét szabályozta. Az egyházközségek tehát maguk határozták meg tanítóik fizetését, így tehát igen nagy különbségek lehettek az állami és az egyházi tanítók fizetése között (Kelemen, 2007. 24. o.). A probléma orvoslásaként népiskolai törvény tanítók fizetésére vonatkozó rendelkezését az 1893. évi XXVI. törvénycikkben kiterjesztették az egyházi iskolák tanítóira is. Emellett az 1893. évi törvény biztosította mind a községi, mind a felekezeti tanítóknak az ötödéves korpótlékot, amely 5 évenként emelkedett 50 krajcártól 250 forintig. Ezt azonban csak azok a tanítók vehették igénybe, akiknek fizetése nem érte el a 300 forintot. Ezt a mindenkori iskolafenntartónak kellett a tanító részére havonként vagy negyedévenként a fizetéssel együtt kifizetni. Ha az iskolafenntartó ezt a terhet nem tudta viselni, illetve az 5 \%-os iskolai pótadó is ki volt merítve, akkor államsegélyért lehetett folyamodni, mellyel a tanító fizetését 400 forintig ki lehetett egészíteni. Az időszakban pozitívumként kell tekintenünk az állami elemi iskolák számának növekedésére, amely 1898-tól volt igazán számottevő. Ezzel párhuzamosan több felekezeti elemi iskola kérte államivá való átalakítását, melynek hátterében az esetek többségében a szúkös anyagi helyzet állt. Ugyancsak előrelépés történt a magyar tannyelv terén is, hiszen míg 1879-ben az elemi iskoláknak csak 46\%-a volt magyar tannyelvú, 1899/1900-ra ez az arány 60 \%-ra emelkedett. Az iskolát látogató tankötelesek száma az évtized folyamán szintén gyarapodott. Míg 1869-ben a tanköteleseknek csak 49 \%-a járt iskolába, az 1893/94-es tanévben ez az arány csaknem 76\%-ra emelkedett, majd a századfordulón már a tanköteleseknek 81\%-a járt iskolába (Felkai, 1994. 57-63. o.). Taneszközök tekintetében az előző időszakhoz képest nem történt jelentős előrelépés. Az iskolák többségében a Kogutowicz-féle, vagy pedig a Lange-féle történelmi képeket használták. A természetrajzi képek közül az ekkorra már elavult Gönczy-félék voltak használatban (Felkai, 1994. 66.). A századforduló időszakának minden kétséget kizáróan a legfontosabb vívmánya a gazdasági ismétlő iskolák megszervezése volt. Az erről szóló rendelet 1896-ban látott napvilágot, mely az általános ismétlő iskolák látogatása terén tapasztalt hibákat igyekezett orvosolni. A rendelet célja, hogy a mindennapi iskolát elvégzett gyerekeknek gyakorlati ismereteket adjon a földmúvelés, az állattenyésztés és a gyümölcstermesztés terén. Az ilyen jellegú ismétlő iskolákat azokban a községekben tették kötelezővé, ahol a lakosság többsége az agrárszektorból élt. Az oktatás 3 évig tartott, télen heti 5, tavasztól őszig heti 2 órában tanították a gyerekeket. Az általános ismétlő iskolákhoz képest ez az iskolatípus sokkal nagyobb sikert könyvelhetett el, a nép körében sokkal nagyobb volt a látogatottsága (Felkai, 1994. 68. o.). Sajnálatos, hogy Romhány esetében nem 
rendelkezünk olyan részletes adatokkal, amelyekből megállapítható lenne az ismétlő iskola, illetve gazdasági ismétlő iskola népszerúségének mértéke, így az nem vethető össze az országos trendekkel.

A XIX. század utolsó évtizedében Romhány iskolájának számos problémával kellett szembenéznie. Többek között ilyen volt a segédtanító fizetésének és nyugdíjjárulékának ügye, a faiskola elhanyagoltsága és gazdátlansága, illetve a tankötelesek nagy száma miatt szükségessé vált második és harmadik tanítói állomás megszervezése, továbbá egy harmadik tanterem felépítése. Munkánk során már szóltunk arról, hogy 1882-től a községben évi 100 forint díjazásért ismét alkalmaztak segédtanítót, akinek a fizetését 5\%-os iskolai adó formájában lélekszám arányában vetették ki a község lakosaira, felekezetre való tekintet nélkül. Ez elégedetlenséget szült, főleg a protestáns földbirtokosok körében, így Laszkáry Gyula 1889-ben meg is fellebbezte ezt a határozatot. 1890-ben azonban ismét napirendre került a segédtanító fizetésének és nyugdíjának ügye, mivel Romhány az 1874 óta alkalmazott segédtanító nyugdíjjárulékát nem fizette, így 16 évi hátralékban volt. Ennek kapcsán a község jegyzője indítványozta, hogy a 100 forint fizetést a községi költségvetésbe vegyék fel, mert a lakosoktól való beszedés bizonytalan volt, ugyanis a szegény családok sokszor nem fizették be. A község képviselőtestülete azonban ettől elhatárolódott, sem a 100 forintos fizetést, sem pedig a nyugdíjjárulékot nem volt hajlandó fizetni, tekintettel arra, hogy az iskola római katolikus felekezetú, így a fenntartónak, vagyis a római katolikus hitközségnek kell a tanító fizetését állnia. ${ }^{54}$ Az 1890 decemberében tartott vármegyei közigazgatási bizottsági közgyúlés jegyzőkönyvéből megtudhatjuk, hogy a község mégis vállalta a hátralékban lévő nyugdíjjárulék megfizetését, valamint a nyugdíjjárulékhoz való községi hozzájárulást is. A segédtanító fizetéséhez pedig évi 40 forinttal járult hozzá, melyből 30 forintot Laszkáry és Prónay földbirtokosok, 10 forintot pedig a plébános adott. A 100 forintnyi fizetéshez még hiányzó 60 forintot a római katolikus felekezetú lakosokra vetették ki adójuk arányában. ${ }^{55}$ 1893-ban ismét napirendre került az ügy, ugyanis a római katolikus iskolaszék kérelmezte, hogy a segédtanítói fizetés terhét a község viselje, továbbá - mivel a 100 forint kevésnek bizonyult - emeljék meg azt évi 150 forintra. A község azonban ismét elzárkózott, továbbá a tanterem és a tanítói szoba fútési költségeinek fedezésétől is. Feltételül szabta, hogy csak abban az esetben hajlandó ezeknek a terheknek a viselésére, amennyiben az iskola felekezeti jellege megszúnik, és községi iskolává alakul át. ${ }^{56}$ A Néptanítók Lapjában közzétett segédtanítói álláshirdetésekből megtudjuk azt is, hogy a segédtanító fizetése 1894-től készpénzben már évi 120 forint volt, valamint a kántortanító általi ellátás és élelmezés 80 forint értékben (Pályázatok (1894.01.10).

\footnotetext{
54 MNL NML V-302, 1. doboz, Képviselőtestületi jegyzőkönyvek 1886-1897. 4/90. kgy. hat.

55 VPKL Püspöki levéltár, Váci Püspöki Hivatal iratai, Iskolai iratok, Schola, Romhány 18951950, 1. doboz, 2098/1894. Utasítás a tanítói állomás szervezése tárgyában, 1894.; MNL NML IV-401, 1. doboz, Nógrád Vármegye Közigazgatási Bizottságának közgyúlési jegyzőkönyve, 354/890. kgy. hat.

56 MNL NML V-302, 1. doboz, Képviselőtestületi jegyzőkönyvek 1886-1897. 12/93. kgy. hat.
} 
Néptanítók Lapja, 27. 3. sz. 30.). Ebből tehát láthatjuk, hogy a segédtanítónak 1894-től is csak az 1893. évi XXVI. tc. által kötelezően előírt minimális 200 forintot adták.

A segédtanító fizetése és nyugdíjjáruléka mellett az 1890-es évek során alapvető problémát jelentett a településen a faiskola állapota is. Az ezzel kapcsolatos problémák azonban nem csak Romhányt érintették, hanem az egész vármegyében jelentkeztek. A faiskolákat a legtöbb helyen az 1850-es illetve az 1860-as években végbement tagosítások alkalmával létesítették abból a célból, hogy a tanulókkal megismertessék a gyümölcstermesztés, illetve a kertészet alapjait. Azonban az intézmény nem váltotta be a hozzá füzött reményeket, ugyanis szinte az egész vármegyében elhanyagolt volt. A községek határának tagosításakor a faiskolákat olyan helyeken jelölték ki, melyre más nem tartott igényt, tehát a faiskolák többsége teljesen hasznavehetetlen területeken létesült. További problémát jelentett, hogy nem rendeltetésüknek megfelelő célra használták, hanem vagy haszonbérbe adták, vagy parlagon hevert, esetleg a tanító saját hasznára ültette be kapásnövényekkel. ${ }^{57} \mathrm{Az}$ 1880-as évekre tehát szükségessé vált a probléma orvoslása. 1881-ben szabályrendeletet alkottak a faiskolák kezeléséről, melyben minden község számára kötelezően előírták a faiskolák létesítését, valamint a már létező faiskolák rendeltetésszerúen történő használatát és bekerítését. Mivel a faiskolák nagy része terméketlen területen volt kijelölve, így a szabályrendelet előírta az ilyen területek cseréjét, továbbá a faiskolák felügyeletére a községi bírókat és jegyzőket, kezelésére pedig a tanítókat utasította. ${ }^{58}$ A faiskolaügy azonban csak nagyon vontatottan haladt előre, így 1883-ban a faiskolákat a Nógrád Megyei Gazdasági Egylet felügyelete alá helyezték. ${ }^{59}$ A probléma azonban sok helyen még az 1890-es években is fennállt, melyet az is bizonyít, hogy 1894-ben törvényt kellett alkotni a faiskolákról és a fásításokról. A részletes szabályozást az 1894. évi XII. tc. VI. fejezete tartalmazza. Romhányban a faiskolaügy 1893-ban vált több ízben is a képviselőtestület napirendi pontjává. A községben az 1861-ben végbement tagosításkor hasítottak ki földet faiskola céljára. A terület azonban a vizenyős talaja miatt nem felelt meg a célnak, ezért a község haszonbérbe adta. ${ }^{60}$ Minden valószínúség szerint az 1864/65-ös tanévről szóló jelentés ezért nem is szól a faiskola létezéséről. ${ }^{61}$ Feltehetően a vármegyei szigorítások miatt a község 1891-ben a régi faiskola helyett egy új, jobb minőségú szántóföldből hasított

\footnotetext{
57 MNL NML XV-15, 494. tekercs, Nógrádi Lapok és Honti Híradó, 10. 12. sz. Valami a szorgalmi kertekről (1882.03.19)

58 MNL NML XV-15, 494. tekercs, Nógrádi Lapok és Honti Híradó, 9. 13. sz. Szabályrendelet a községi faiskolákról (1881.03.27)

59 MNL NML XV-15, 495. tekercs, Nógrádi Lapok és Honti Híradó, 11. 50. sz. Cantatio post festa (1883.12.16)

60 MNL NML V-302, 1. doboz, Képviselőtestületi jegyzőkönyvek 1886-1897. 12/93. kgy. hat.

61 VPKL Püspöki levéltár, Váci Püspöki Hivatal iratai, Iskolai iratok, Informatio scholaris, 4. doboz 1860-1865, Táblázat a Romhányi egyházközségben lévő népiskolák állapota iránt az 1865. tanévben
} 
ki 1 holdnyi területet, melyet haszonbérbe adtak 7 forint 80 krajcárért, illetve azzal a feltétellel, hogy a bérlő köteles a területet vad gyümölcsfacsemetékkel beültetni. Emellett a község rendelkezett még egy - a Topolyos nevú területből kihasított - 100 négyszögöl kiterjedésû szederfaiskolával is. ${ }^{62}$ Problémát jelentett azonban, hogy a helyi kántortanító, Trautwein Gyula a gyümölcsfák oltásában és kezelésében járatlan volt, de szándékot sem tanúsított a faiskolák iránt, így azok kezelésével az egyik uradalmi kertészt bízták meg. ${ }^{63}$ A község tudatában volt annak, hogy a faiskolák helyzete tarthatatlan, viszont megoldást csak abban látott, ha vezetésüket a kántortanító veszi át. Erre nem utasíthatta, ugyanis ez a római katolikus iskolaszék hatáskörébe tartozott, viszont a község faiskolaügy melletti elkötelezettségét mutatta, hogy hajlandónak mutatkozott a faiskolák fenntartásával járó költségek fedezésére, valamint a kántortanító pénzbeli jutalmazására is. Hogy megoldódjon a faiskola ügye, a képviselőtestület 1893-ban kérvényt intézett a vármegyéhez, hogy eszközölje ki az egyházmegyei hatóságnál a kántortanító faiskola kezelésére való utasítását. ${ }^{64}$

A 6-12 éves tanköteles gyermekek száma az 1890-es évek elején jelentősen megnövekedett mind a vármegye, mind pedig a község esetében. Vármegyei szinten a legnagyobb mértékú növekedést az 1891/92-es illetve az 1892/93-as tanév között figyelhetjük meg, mértéke 17,6\% volt. Romhány esetében a legnagyobb mértékú növekedést az 1889/90-es, illetve az 1890/91-es tanév között figyelhetjük meg, ekkor a növekedés mértéke 22,4\% volt. Az elemi iskolai tankötelesek száma a községben azonban az 1890/91-es tanévtől az 1892/93-as tanévig tartósan magas volt, 218-234 fő között alakult, majd az 1893/94-es tanévben hirtelen 187 főre csökkent, ami megegyezett az 1887/88-as szinttel. Az elemi iskolába ténylegesen járó gyermekek száma a vármegye egészében szintén növekedést mutatott az 1890-es évek elején. Községünk esetében azonban nem figyelhetünk meg ilyen tendenciát, ugyanis egyik tanévben magasabb, másik tanévben alacsonyabb volt az elemi iskolát látogatók száma. Az 1889/90-es, illetve az 1890/91-es tanév között 39 fővel gyarapodott a mindennapi iskolát látogatók száma. Az 1893/94-es tanévre ezen a téren is nagy csökkenés figyelhető meg, ebben a tanévben 49-cel kevesebb gyermek járt iskolába, mint az előzőben. Az elemi iskolát látogató gyermekek arányának vizsgálatakor az eddigiektől eltérő képet kaptunk. Nógrád vármegyében az 1891/92-es és az 1893/94-es tanév között a tankötelesek 80-90\%-a járt iskolába. Községünk esetében ugyanezekben a tanévekben a 6-12 éves tanköteles gyermekeknek 83-88\%-a látogatta a tanodát, mely az 1889/90-es és az 1890/91-es tanév során tapasztalt 90-91\%-os arányhoz képest romlott. Az 1891/92-es tanévre az elemi iskolát látogató gyermekek aránya 92,2\%-ról 84,7\%-ra esett vissza. Hasonló csökkenést figyelhetünk meg az $1893 / 94$-es tanévben is, ekkor $88 \%$-ról $84 \%$-ra esett vissza. ${ }^{65}$

\footnotetext{
62 MNL NML V-302, 1. doboz, Képviselőtestületi jegyzőkönyvek 1886-1897. 12/93. kgy. hat.

63 MNL NML V-302, 1. doboz, Képviselőtestületi jegyzőkönyvek 1886-1897. 1/93. kgy. hat.

64 MNL NML V-302, 1. doboz, Képviselőtestületi jegyzőkönyvek 1886-1897. 9/93. kgy. hat.

65 Magyar Statisztikai Évkönyv. Új Folyam 1893-1899. Országos Magyar Királyi Statisztikai
} 
A tanköteles gyermekek nagy számából eredő infrastruktúrahiányt a korban is aggasztónak találták, ugyanis az 1894. május 4-én iskolalátogatást tartó királyi tanfelügyelő elrendelte a harmadik tanterem felépítését. ${ }^{66}$ Ugyanezen év őszén a váci püspök is „siralmas" jelzővel illette a romhányi tanügyi állapotokat, melynek okát a második tanítói állomás hiányában látta. ${ }^{67}$ A községbe ugyanis évente kerestek segédtanítót, melyet aztán vagy sikerült szerezni, vagy nem. Például az 1889/90-es tanévben nem találtak segédtanítót, így az egyik osztályt a káplán tanította. Az 1890-es évek első felében a településen segédtanítóként múködött 1890-92-ig Sipos Jenő, majd 1-1 tanéven át Stevola Péter és Lehoczky Sándor. ${ }^{68}$

1894 nyarán tehát napirendre került, hogy a segédtanítói állomást a tankötelesek nagy száma miatt rendes tanítói állomássá kell átalakítani, továbbá egy harmadik tanítói állomást, egy harmadik tantermet és két tanítói lakást kell létesíteni. A segédtanító fizetését államsegély útján 300 forintra kívánták kiegészíteni, amennyiben azt rendes tanítói állomássá szervezik át. ${ }^{69}$ A tanító fizetésének az 5\%-os iskolai adó útján való fedezéséből azonban vita pattant ki az iskolaszék, a földbirtokosok és a plébános között. A plébános és a püspök az 5\%-os iskolai adót a hitközség tagjaira akarta kivetni, az iskolaszék azonban ez elől elzárkózott, csak a felekezet nélküli politikai községre való kivetést volt hajlandó megszavazni. Az evangélikus földbirtokosok viszont csak akkor szavazták volna meg a felekezet nélküli adókivetést, ha az iskola római katolikus felekezeti jellege megszúnik és községi iskolává alakul át. ${ }^{70}$ A püspök azonban erről hallani sem akart, így utasította a plébánost, hogy a segédtanítói állomás önállósítása után a tanítónak járó évi 300 forint fizetését a hitközségtől 5\%-os iskolai adó formájában beszedett 143 forint 57 krajcárból, illetve az államsegélyként kért 156 forint 43 krajcárból fedezzék. ${ }^{71}$ Ilyen feltételek mellett 1894 szeptemberében Szotfrid József acsai születésû́ tanítót választották meg segédtanítónak évi 120 forint készpénzbeli, továbbá a kántortanító által nyújtott 80 forint értékú ellátás fejében. A már kérelmezett államsegély elnyerése után a segédtanító állomását rendes tanítóivá akarták átalakítani, fizetését pedig 300 forintra kiegészíteni. A

Hivatal, Budapest, 1894-1900.

VPKL Püspöki levéltár, Váci Püspöki Hivatal iratai, Iskolai iratok, Informatio scholaris, 8-9. doboz 1889-1904, Informatio scholaris Districtus Romhány 1890-1894.

66 VPKL Püspöki levéltár, Váci Püspöki Hivatal iratai, Iskolai iratok, Schola, Romhány 1895-1950, 1. doboz, 2098/894. Utasítás a tanítói állomás szervezése tárgyában, 1894.

67 VPKL Püspöki levéltár, Váci Püspöki Hivatal iratai, Iskolai iratok, Informatio scholaris, 9. doboz 1893-1904, 3909/894. Informatio scholaris Districtus Romhány, 1894.

68 VPKL Püspöki levéltár, Váci Püspöki Hivatal iratai, Iskolai iratok, Informatio scholaris, 8-9. doboz 1889-1904, Informatio scholaris Districtus Romhány 1890-1894.

69 VPKL Püspöki levéltár, Váci Püspöki Hivatal iratai, Iskolai iratok, Schola, Romhány 1895-1950, 1. doboz, 2098/894. Utasítás a tanítói állomás szervezése tárgyában, 1894.

70 VPKL Püspöki levéltár, Váci Püspöki Hivatal iratai, Iskolai iratok, Schola, Romhány 18951950, 1. doboz, 2793/894. Előterjesztés a romhányi második önálló tanítói állomás szervezése tárgyában, 1894.

71 VPKL Püspöki levéltár, Váci Püspöki Hivatal iratai, Iskolai iratok, Schola, Romhány 1895-1950, 1. doboz, 3313/894. A plébános aggályai a tanítói állomás szervezése körül, 1894. 
megválasztott segédtanító azonban a tanév megkezdése után 2 nappal lemondott, mert a váci siketnémák intézetében kapott állást. Így tehát a romhányi iskola 200 elemi iskolás tankötelezettje egyetlen tanítóra, Trautwein Gyulára maradt. ${ }^{72}$ Mivel a kántortanító ennyi diákot képtelen volt egyszerre tanítani, így csak a 90 felsőbb éves gyermek járt iskolába. Az 1894/95-ös tanévben tehát a 110 kisebb gyermek tanítását a 2 káplánra akarták bízni, akik ezt az államsegély elnyerése fejében hajlandóak is voltak elvállalni. Ellenkező esetben tartani lehetett az iskola bezárásától, hiszen nem volt tanító. A váci püspök ezt 1894 decemberében engedélyezte is, melyre a vallás- és közoktatásügyi miniszter jóváhagyását kérte. ${ }^{73}$

1896 nyarán sok viszontagság után megvalósult a községben a második és a harmadik tanítói állomás megszervezése. A második tanítói állomásra Hartl György perbetei tanítót választották meg évi 400 forint fizetésért, amelyből 143 forintot a hitközség által, 257 forintot pedig államsegély formájában fedeztek. A harmadik tanítói állomást Pergő József vadkerti tanító töltötte be, fizetése szintén évi 400 forint volt, melyet teljes egészében államsegély formájában fedeztek. A készpénzbeli fizetésen kívül mindkét tanítót megilletett egy 1 szobás lakás, illetve egy $1 \frac{1}{2}$ hold területú kert. ${ }^{74}$ Láthatjuk tehát, hogy a tanítók fizetését az évi minimális 300 forint helyett államsegéllyel évi 400 forintra egészítették ki az 1893. évi XXVI. tc. alapján. A tanítók megválasztásával megoldódott a faiskola szakszerú kezelésének ügye is, melyért a község képviselőtestülete évente 20 forint jutalmat szavazott meg. ${ }^{75}$

Miután a 3 rendes tanítói állomás felállítása megtörtént, hozzá kellett látni a harmadik tanterem felépítéséhez. Mivel az iskolaépület a község tulajdona volt, s az épületet is a község tartotta fenn, így a községi képviselőtestületnek kellett gondoskodnia az építkezésről. 1894-ben a községet egy nyári gyermekmenhely mai nevén napköziotthon - építésére kötelezték, így a képviselőtestület 1896-ban felvetette, hogy a menedékházat úgy is fel lehet építeni, hogy az egyben iskola és tanítói lakás is legyen. Tehát igyekezett a kötelezettségét költséghatékonyan teljesíteni. Mivel az építkezés előkészületei előreláthatólag hosszabb időt vettek igénybe, s az nem volt kivitelezhető az 1896/97-es tanév kezdetéig, így erre az iskolai évre a község egy lakóházat bérelt ki harmadik tanterem és tanítólak

\footnotetext{
72 VPKL Püspöki levéltár, Váci Püspöki Hivatal iratai, Iskolai iratok, Schola, Romhány 1895-1950, 1. doboz, 4330/894. Előterjesztés a romhányi iskolai állapotokról, 1894.

73 VPKL Püspöki levéltár, Váci Püspöki Hivatal iratai, Iskolai iratok, Schola, Romhány 18951950, 1. doboz, 5069/894. Az iskolaszék kérelme az iránt, hogy engedje meg a káplánoknak az iskolában a tanító helyettesítését, 1894.

VPKL Püspöki levéltár, Váci Püspöki Hivatal iratai, Iskolai iratok, Schola, Romhány 18951950, 1. doboz, 5268/894. Folyamodvány a nagyméltóságú vallás és közoktatási magyar királyi minisztériumhoz, melyben a káplánok részére tanítási engedély kéretik, 1894.

74 VPKL Püspöki levéltár, Váci Püspöki Hivatal iratai, Iskolai iratok, Schola, Romhány 18951950, 1. doboz, 3231/896. A tanítók választásáról felvett jegyzőoönyv jóváhagyásra felterjesztetik, 1896.

75 MNL NML V-302, 1. doboz, Képviselőtestületi jegyzőkönyvek 1886-1897. 7/96. kgy. hat.
} 
gyanánt, melyet a szükséges taneszközökkel és padokkal be is rendeztek. ${ }^{76}$ Még 1896 augusztusában a képviselőtestület hozzálátott a létesítendő tanterem helyének kiválasztásához. Mivel évtizedek óta problémát jelentett a községben, hogy a Domb és Pást nevú falurészen élő gyermekeknek naponta 2-3 km-t kellett megtenniük az iskoláig, melyet esős és téli időszakban a sáros utak, illetve a Lókos-patak áradásai még jobban megnehezítettek, így célszerúnek látták, hogy az új tantermet a Dombon építsék fel. Erre találtak is egy - a község tulajdonát képező - beépítetlen közteret, ahol a gyermekeknek megfelelő területû́ udvart is tudtak volna biztosítani. ${ }^{77} 1897$ februárjában azonban ezt az elképzelést módosítani kellett, ugyanis, bár indokolt lett volna a tanterem Dombon történő felépítése, azonban ennek kivitelezése több ezer forintba került volna, továbbá szükségessé tette volna egy 4 . tanítói állás megszervezését is. A község azonban csak 600-700 forintnyi fedezettel rendelkezett, így a dombi iskola kivitelezésére képtelen lett volna. Ebből kifolyólag a képviselőtestület úgy döntött, hogy a község „Falu” nevú részén lévő régi iskolaházat bővíti ki úgy, hogy az 3 tanteremből és 2 tanítói szobából álljon. Az építkezést 1897 nyarára tervezték kivitelezni. ${ }^{78} 1897$ tavaszán azonban Nógrád Vármegye Közigazgatási Bizottságának nyomására a képviselőtestület elhatározta, hogy egy községi fenntartású gazdasági ismétlő iskolát létesít. Ennek feltételei a településen adottak is voltak, ugyanis rendelkezett megfelelő faiskolával és kertészeti szerszámokkal, a 3 helybeli tanító az ismétlő iskolában való tanítást elvállalta, továbbá az év nyarán kibővíteni tervezett elemi iskolában tantermek is rendelkezésre álltak volna. Az ismétlő iskola fenntartását a politikai községre kivetett - még fel nem használt - 5\%-os iskolai adóból kívánták fedezni, mely 59 forintot és 40 krajcárt tett volna ki. Csupán a tanítók tiszteletdíjára nem volt fedezet, erre viszont államsegélyt kívántak kérni. ${ }^{79} 1897$ júliusában hozzákezdtek a felekezeti iskola épületének kibővítéséhez, melyet a tanév kezdetére be is fejeztek. Az építkezés költsége összesen 1747 forintra rúgott, mely összeget a község pénztári maradványából, a különféle alapokból vett kölcsönből, továbbá az alispántól a közmunkaalapból kölcsönként kérelmezett 208 forintból teremtették elő. ${ }^{80}$

A községi fenntartású gazdasági ismétlő iskola megalapítása negatív hatást is gyakorolt a felekezeti iskolára, ugyanis eddig szokásban volt, hogy az iskola fútési költségeihez a földbirtokosok is hozzájárultak. Az 1898/99-es tanévtől azonban ezt az adományt megtagadták a felekezeti iskolától, de a gyermekek sem hordtak fát az iskolába, mert csak drágán lehetett beszerezni. Fadeputátum hiányában az 1898/99-es tanévben a községben lévő tantermek heteken keresztül fútetlenek voltak, ezért az 1899/1900-as tanévre szóló költségvetésbe fel kellett venni a fútés címén 138 forintot, viszont fedezet nem volt rá. Az

\footnotetext{
76 MNL NML V-302, 1. doboz, Képviselőtestületi jegyzőkönyvek 1886-1897. 5/96. kgy. hat. MNL NML V-302, 1. doboz, Képviselőtestületi jegyzőkönyvek 1886-1897. 6/96. kgy. hat. MNL NML V-302, 1. doboz, Képviselőtestületi jegyzőkönyvek 1886-1897. 2/97. kgy. hat. MNL NML V-302, 1. doboz, Képviselőtestületi jegyzőkönyvek 1886-1897. 6/97. kgy. hat. MNL NML V-302, 1. doboz, Képviselőtestületi jegyzőkönyvek 1886-1897. 8/97. kgy. hat.
} 
eloállt helyzet megoldásának reményében a plébános kérvényezte a püspöktől, hogy a tanítók fizetését államsegély útján emeltesse meg 138 forinttal, amely nyomán fedezetet nyerne az iskola fútési kiadása. A püspök azonban az engedélyt megtagadta, hiszen államsegélyt csak a 400 forintnál kevesebb fizetéssel rendelkező tanítók kaphattak, Romhányban viszont a tanítók fizetése elérte ezt az összeget. ${ }^{81}$ Ehhez kapcsolódóan egy másik problémával is meg kellett küzdenie a romhányi tanodának, illetve az azt fenntartó hitközségnek. Még 1896-ban azzal a feltétellel választották meg Pergő és Hartl tanítókat, hogy csak 1-1 szobából álló lakást kapnak. 1899-re azonban ismét előtérbe került az ügy, ugyanis Nógrád Vármegye Közigazgatási Bizottsága februárban határozatot hozott arról, hogy a romhányi iskolaszéknek a törvény erejénél fogva kötelessége a tanítói részére lakás, illetve lakáspénz biztosítása. A hitközség azonban erre szegénységénél fogva képtelen volt, ugyanis sem telekkel, sem pedig a tanítói lakás felépítéséhez elegendő készpénzzel nem rendelkezett. Átmeneti megoldásként - az alispán nyomására - felajánlotta a tanítóknak, hogy lakás és kertilletmény helyett évi 100-100 forintot ad a lakáspénzként, negyedévenkénti 25 forintos részletekben, de csak abban az esetben, ha az államtól segélyként kért 138 forintot megkapja. A hitközség segélykérelmét azonban elutasították. Ugyanezen év szeptemberében a Közigazgatási Bizottság határozatot hozott arról, hogy az 1893. évi XXVI. törvénycikknek megfelelően a tanítóknak legalább két padozott szobából, egy konyhából és egy kamrából álló lakást kell biztosítani, s ez a romhányi iskola tanítóira nézve is kötelező érvényú volt. Figyelembe véve azonban a hitközség szegénységét, a tanítói lakások és illetmények rendezésére 1900. szeptember 1-ig haladékot engedélyezett. Az így kialakult helyzet miatt a tanítók is türelmetlenek voltak. Pergő József 1899 októberében kérvényt intézett a főszolgabíróhoz, hogy hajtsa be a hitközség által még áprilisban megígért 100 forint lakáspénzt, melynek első részletét szeptemberben kellett volna kifizetni. A kérvény rendkívül értékes számunkra, ugyanis képet kaphatunk egy XIX. század végi falusi tanító anyagi helyzetéről. Pergő tanító a saját helyzetét a következőképpen mutatta be: ",...] ki ismeri egy 400 forintos tanítónak amúgy is nyomorúságos s annyiszor epébe mártott kenyerét s kinek osztályrészül nem jut más, mint egy-egy rúgás azoktól, kik kenyeret úgyse tudnak adni [...]".82 A tanító valóban szúkös körülmények között élhetett, ugyanis annak ellenére, hogy a hitközség a tanítói illetmények rendezésére csaknem 1 évnyi haladékot kapott a Közigazgatási Bizottságtól, mégis egy korábbi megállapodásra hivatkozott, miszerint a hitközség ígéretet tett arra, hogy 1899 szeptemberétől fizet. A község plébánosa azonban másképpen látta a tanító helyzetét, melyet a következő szavakkal mutatott be a főszolgabírónak: „[...] Pergő József tanító úrnak lakás miatt panasznyújtásra

\footnotetext{
81 VPKL Püspöki levéltár, Váci Püspöki Hivatal iratai, Iskolai iratok, Schola, Romhány 18951950, 1. doboz, 1775/899. A tanítók fizetésének fedezésére az államsegély 138 forinttal felemeltetni kéretik, 1899.

82 MNL NML V-302, 5. doboz, 1381/899. Pergő József romhányi tanító kérvénye tanítói fizetésének behajtása tárgyában, 1899 .
} 
oka sem lehet, mert ő neki, mint nőtlen fiatal embernek, oly tisztességes egy szobából álló lakása van, melyben a legkényesebb természetü úri ember is el lakhatik [...]" 83 A főszolgabíró Pergő József kérelmét egyelőre elutasította, mivel a hitközség az illetmények rendezésére haladékot kapott. A tanítói lakás ügyében az iskolaszék a politikai községtől kívánt segítséget kérni, mégpedig oly módon, hogy a tulajdonában álló kovácslakot adja át a hitközségnek, s abból egy tanítói lakást és egy tantermet alakítsanak ki, valamint a jelenlegi iskolaházat is alakítsák át úgy, hogy a törvény rendelkezéseinek megfeleljen. ${ }^{84} \mathrm{Az}$ ügy további fejleményeiről források hiányában nincs tudomásunk.

Az 1898/99-es tanév során másik veszteség is érte az iskolát, ugyanis 1898. december 6-án elhunyt az iskolaügy egyik legfőbb támogatója, Bagyinszky Frigyes iskolaszéki és képviselőtestületi tag. A tanodáról halála után is kívánt gondoskodni, így 600 koronát hagyományozott a községnek, - ami egy rendes tanító egy évi minimális fizetését jelentette - hogy azt iskolai célokra fordítsák, viszont az összeget csak felesége halála után kaphatták kézhez. ${ }^{85}$ A Bagyinszkyhagyomány sorsának tárgyalása azonban tanulmányunk időbeli keretein kívül esik.

A XIX. század legvégére tehát egy 3 tanteremből álló iskolával, egy gazdasági ismétlő iskolával, valamint 3 rendes, okleveles tanítóval büszkélkedhetett a község, akik hosszú éveken keresztül végezték a romhányi gyermekek oktatását és nevelését. A század végére az iskolalátogatók arányában is nagymértékú javulás következett be, ugyanis az 1899/1900-as tanévben a tankötelesek 100 \%-a járt iskolába, míg Nógrád vármegye egészére nézve ez csak $83 \%$ volt. A tanodában a diákok vallástant, olvasást és írást, számtant, földrajzot, természetrajzot, természettant, polgári jogi ismereteket, történelmet, éneket és testgyakorlatot tanultak. Tankönyvként továbbra is a Szent István Társulat tankönyveit használták. Az iskola tanszerekkel megfelelően el volt látva, a tantermekben megtalálhatóak voltak a fali táblák, a számológép, a természetrajzi és természettani ábrák, földgömb, valamint Magyarország és Európa térképe is. ${ }^{86}$

A romhányi iskolaügy régmúltját áttekintve láthatjuk, hogy a vizsgált időszak közel sem volt nyugodt a községben. Az oktatás felekezeti jellege, illetve az iskolaépület és a tárgyi feltételek község által való biztosításának kötelessége állandó vita tárgyát képezte, mely azt az érzést kelti, hogy az iskolának valójában nem volt igazi gazdája. Az 1868-as népoktatási törvény elvárásainak való

\footnotetext{
83 MNL NML V-302, 5. doboz, 1381/899. Pergő József romhányi tanító kérvénye tanítói fizetésének behajtása tárgyában, 1899.

84 MNL NML V-302, 5. doboz, 1381/899. Pergő József romhányi tanító kérvénye tanítói fizetésének behajtása tárgyában, 1899.

${ }^{85}$ MNL NML V-302, 1. doboz, Közgyúlési jegyzőkönyvek 1903-1907. 9/904. kgy. hat.

Az 1892. évi XVII. tc. értelmében új pénznemként vezették be a koronát, s az összehasonlíthatóság kedvéért közöljük, hogy 1 ezüst forint 2 ezüst koronával egyezik meg.

86 VPKL Püspöki levéltár, Váci Püspöki Hivatal iratai, Iskolai iratok, Informatio scholaris, 9. doboz 1893-1904, 3163/1900. Értesítvény a rományi római katolikus népiskoláról az 1899/1900 tanévre.
} 
megfelelés éppen ezért sok esetben nehézségekbe ütközött. Mindezek mellett - ha a tankötelesek és az iskolát látogatók arányát vizsgáljuk - láthatjuk, hogy az iskola igyekezett megfelelni a vele szemben támasztott elvárásoknak, sok esetben jobb arányt mutatva a megyei és az országos trendeknél. A levéltári forrásokat, a statisztikai adattárakat és a szakirodalmat felhasználva igyekeztünk megrajzolni Romhány község iskolaügyének történetét a vizsgált időszakban, $\mathrm{s}$ ahol erre lehetőség kínálkozott, ott a kapott adatokat, információkat megyei illetve országos kontextusba ágyazva vizsgáltuk. A legtöbb esetben azt láthatjuk, hogy a helyi adatok kedvezőbbek, mint az országos vagy éppen a megyei értékek. A romhányi iskolát tehát a nehézségek ellenére is sikeresnek, viszonylag népszerúnek tekinthetjük. Tanulmányunkban láthattuk, hogy a XIX. században tapasztalható fejlődés mellett számos probléma is jelen volt, hiszen a község, illetve az iskolát fenntartó hitközség anyagi erejénél fogva sokszor nem tudott megfelelni a törvények rendelkezéseinek. Bár a fejlődés tagadhatatlan, a nehézségek még a XX. században is érezhető módon nyomták rá bélyegüket a község népoktatásának ügyére.

\section{LEVÉLTÁRI FORRÁSOK}

Magyar Nemzeti Levéltár Nógrád Megyei Levéltára (MNL NML) IV-1/b Megyei törvényhatóságok, Nógrád Vármegye Nemesi Közgyúlésének iratai, Közgyúlési iratok (1610-1848), 390. doboz

Magyar Nemzeti Levéltár Nógrád Megyei Levéltára (MNL NML) IV-152/b, Megyei törvényhatóságok, A Nógrádi Császári Királyi Megyehatóság iratai, Megyefónöki általános iratok (1850-1860), 105, 120. doboz

Magyar Nemzeti Levéltár Nógrád Megyei Levéltára (MNL NML) IV-401, Megyei törvényhatóságok, Nógrád vármegye főispánjának iratai (1872-1923), 1. doboz

Magyar Nemzeti Levéltár Nógrád Megyei Levéltára (MNL NML) V-302, Mezővárosok, rendezett tanácsú városok, községek, Romhány nagyközség iratai (1886-1950), 1, 5. doboz

Magyar Nemzeti Levéltár Nógrád Megyei Levéltára (MNL NML) VI-501, A központi államigazgatás területi szervei, Nógrád Vármegye Tanfelügyelőségének iratai (1870-1950), 1. doboz

Magyar Nemzeti Levéltár Nógrád Megyei Levéltára (MNL NML) XV-15, Gyứjtemények, Mikrofilmek gyứjteménye, Nógrádi Lapok és Honti Híradó (1873-1890) 493-496. tekercs

Magyar Nemzeti Levéltár Országos Levéltára, C, Helytartótanácsi Levéltár, Magyar Királyi Helytartótanács regisztratúrája, C 69 Departamentum scholarum nationalium (1776-1848), Normalia, 1845

Váci Püspöki és Káptalani Levéltár (VPKL) Püspöki levéltár, Váci Püspöki Hivatal iratai, Acta Parochiarum, Romhány, 1. doboz 1774-1869 
Váci Püspöki és Káptalani Levéltár (VPKL) Püspöki levéltár, Váci Püspöki Hivatal iratai, Iskolai iratok, Acta scholastica, 1. doboz 1736-1845

Váci Püspöki és Káptalani Levéltár (VPKL) Püspöki levéltár, Váci Püspöki Hivatal iratai, Iskolai iratok, Informatio scholaris 1770-1900. Váci Püspöki és Káptalani Levéltár (VPKL) Püspöki levéltár, Váci Püspöki Hivatal iratai, Iskolai iratok, Schola, Romhány 1895-1950, 1. doboz

Váci Püspöki és Káptalani Levéltár (VPKL) Plébániai levéltár, A romhányi r.k. plébánia iratai 1702-1997.

\section{FELHASZNÁLT IRODALOM}

Chobot Ferenc (1913): A romhányi plébánia története. Szent István Társulat, Budapest. 23.

Ezer év törvényei. Letöltés: https://1000ev.hu/ Letöltési idő: 2017. április

Felkai László (1994): Magyarország oktatásügye a millennium körüli években. Országos Pedagógiai Könyvtár és Múzeum, Budapest.

Kelemen Elemér (2007): A tanító a történelem sodrában. Tanulmányok a magyar tanítóság 19-20. századi történetéből. Iskolakultúra, Pécs.

Magyar Statisztikai Évkönyv. Új Folyam 1893-1899. (1894-1900) Országos Magyar Királyi Statisztikai Hivatal, Budapest.

Mészáros István, Németh András és Pukánszky Béla (2003, szerk.): Neveléstörténet. Bevezetés a pedagógia és az iskoláztatás történetébe. Osiris Kiadó, Budapest.

Néptanitók Lapja (1874). 7. 14. és 24. sz.

Pályázatok (1875.09.30). Néptanítók Lapja, 8. 18. sz. 325.

Pályázatok (1882.09.09). Néptanítók Lapja. 15. 36. sz. 572.

Pályázatok (1894.01.10). Néptanítók Lapja. 27. 3. sz. 30.

Nóbik Attila (2006): Népiskolai tanitóság a 19. századi neveléstörténeti tankönyvek tükrében. Iskolakultúra, 16. 4. sz. 41-48.

Pacséri Károly (1900, szerk.): Nógrádvármegye népoktatásának története. Balassa Gyarmati Könyvnyomda Részvénytársaság, Balassa Gyarmat.

Pukánszky Béla - Nóbik Attila (2015): A magyar iskoláztatás története a 1920. században. Letöltés: http://www.jgypk.hu/mentorhalo/tananyag/Magyar_ isk_tortenete/index.html Letöltési idő: 2017. április 23. 